\title{
VIABILIDADE CELULAR DE Saccharomyces cerevisiae EM CULTURA MISTA COM Lactobacillus fermentum
}

\section{ROSANA MARIA DE OLIVEIRA FREGUGLIA}

\author{
Bióloga
}

Orientador: Prof. Dr. JORGE HORII

\begin{abstract}
Dissertação apresentada à Escola Superior de Agricultura "Luiz de Queiroz", Universidade de São Paulo, para a obtenção do título de Mestre em Ciências, Área de Concentração: Ciência e Tecnologia de Alimentos.
\end{abstract}

P I R A C I C A B A

Estado de São Paulo - Brasil

Novembro - 1997 
Dados Internacionais de Catalogação na Publicação (CIP) DIVISÃo DE BIBLIOTECA E dOCUMENTAÇÃo - Campus "Luiz de Queiroz"/USP

Freguglia, Rosana Maria de Oliveira

Viabilidade celular de Saccharomyces cerevisiae em cultura mista com Lactobacillus fermentum / Rosana Maria de Oliveira Freguglia. - Piracicaba, 1997

104 p. : it.

Dissertação (mestrado) - - Escola Superior de Agricultura Luiz de Queiroz, 1997. Bibliografia.

1. Bactéria lácticas 2. Contaminação bacteriana 3. Cultura mista 4. Fermentaçăo alcoólica I. Titulo

CDD 663.13 


\section{VIABILIDADE CELULAR DE Saccharomyces cerevisiae EM CULTURA MISTA COM Lactobacillus fermentum}

\section{ROSANA MARIA DE OLIVEIRA FREGUGLIA}

Aprovada em: 22.01 .98

Comissão julgadora:

Prof. Dr. Jorge Horii

Prof. Dr. Antonio Joaquim de Oliveira

Prof. Dr. Sérgio Florentino Pascholate
ESALQ/USP

ESALQ/USP

ESALQ/USP

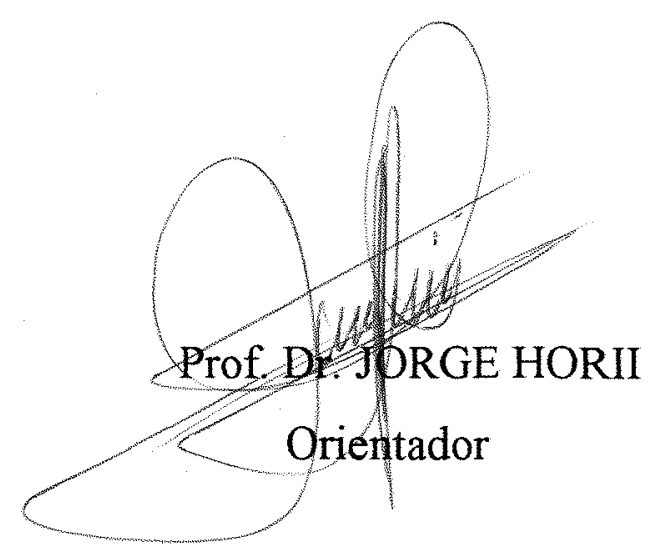


À ISABELLA, minha filha e companheira, pelo amor e carinho

Ao meu esposo CÉLIO e aos meus pais, CIDINHA e ROBERTO, pelo amor e incentivo 


\section{AGRADECIMENTOS}

À DEUS pela graça de mais esta conquista.

Agradeço a todos aqueles que de alguma forma contribuíram para a realização deste trabalho, especialmente:

- Ao Prof. Dr. Jorge Horii, pela orientação, confiança e amizade;

- À CAPES pela concessão da bolsa de estudos;

- Ao Prof. Dr. Elliot Kitajima pela contribuição e concessão do laboratório onde foram realizadas as fotografias;

- Ao Prof. Dr. Cyro Meirelles em especial pelo apoio na elaboração do "Summary";

- À amiga Regina Helena Gonçalves, pela amizade e pelas valorosas contribuições;

- Aos amigos Carlos Alberto França Ribeiro, André Vinicius Sesso, André Eduardo Belluco e Beatriz Mastrodi, pela amizade; 
- Aos amigos Valmir Eduardo Alcarde, Carlos Eduardo Garcia e Cleomar Maria de Carvalho, pelas sugestões e amizade;

- Aos amigos Luiz Carlos Rodrigues, Rubens Cesar Pereira, Sylvino Luiz Torrezan, Gislaine Maria Nóbilo, Rosemary Mandro e Regina Lucia Lourenço, pela amizade e auxílios prestados;

- Às bibliotecárias Beatriz Helena Giongo e Mídiam Gustinelli, pela colaboração e auxílios prestados;

- Ao Departamento de Ciência e Tecnologia Agroindustrial da Escola Superior de Agricultura "Luiz de Queiroz" da Universidade de São Paulo, pela oportunidade e pelos recursos fornecidos;

- À todos os professores que contribuíram para a minha formação científica, e às demais pessoas que direta ou indiretamente auxiliaram na execução deste trabalho. 


\section{SUMÁRIO}

LISTA DE FIGURAS ............................................................... iv

LISTA DE TABELAS _............................................................ vi

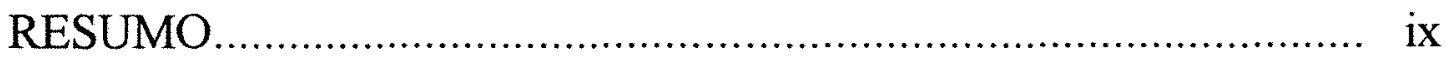

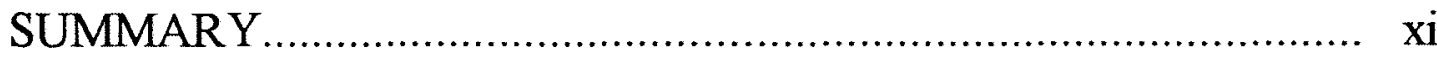

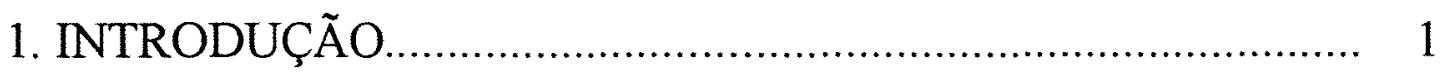

2. REVISÃO BIBLIOGRÁFICA ................................................. 3

2.1. Contaminantes do processo de produção de álcool........................ 3

2.1.1. Matéria-prima............................................................. 3

2.1.2. Processamento da matéria-prima......................................... 5

2.1.3. Fermentação alcoólica......................................................... 8

2.2. Bactérias produtoras de ácido láctico .................................... 13

2.2.1. Algumas características das bactérias lácticas........................ 14

2.2.2. Influência da contaminação por bactérias lácticas na

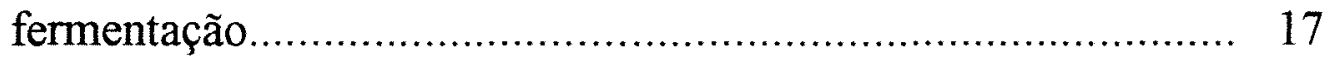

2.3. Floculação de leveduras........................................................ 18

2.4. Floculação de leveduras causada por bactérias............................ 23

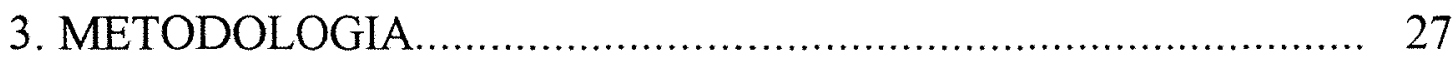

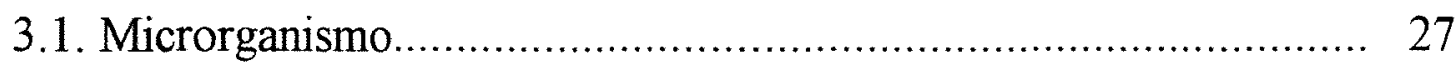


3.2. Meios de cultura …............................................................ 27

3.2.1. Meios de manutenção e reativação dos microrganismos........... 28

3.2.2. Meios de cultura desenvolvidos para crescimento dos

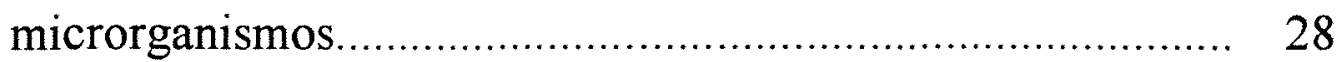

3.2.2.1. Matéria-prima e extração do caldo........................................ 29

3.2.2.2. Preparo do meio de cultura.......................................... 29

3.3. Determinações físico-químicas............................................... 30

3.4. Determinações microbiológicas............................................. 30

3.4.1. Viabilidade celular....................................................... 31

3.4.2. Semeadura em placas........................................................ 31

3.4.2.1. Semeadura em profundidade ............................................. 32

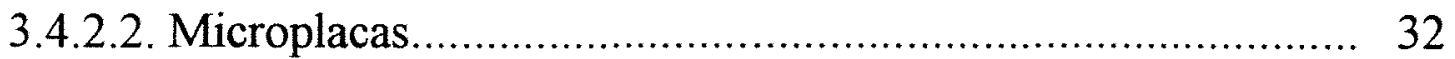

3.5. Cultivo de $S$. cerevisiae e L. fermentum................................. 35

3.5.1. Cultivo de $L$. fermentum ..................................................... 35

3.5.2. Cultivo de $S$. cerevisiae ....................................................... 36

3.6. Composição das culturas mistas de L. fermentum e de

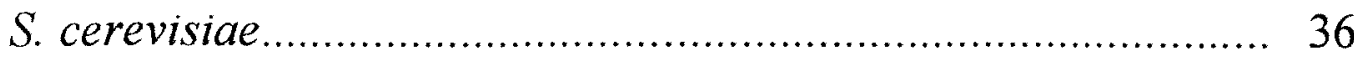

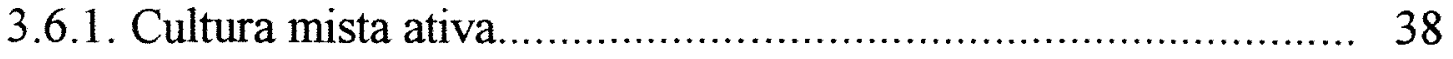

3.6.2. Cultura mista inativada ..................................................... 38

3.6.2.1. Cultura mista inativada por esterilização............................. 38

3.6.2.2. Cultura mista inativada por agentes antibacterianos............... 39

3.7. Tratamentos com enzimas e a capacidade floculante de

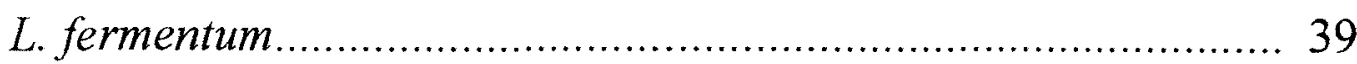

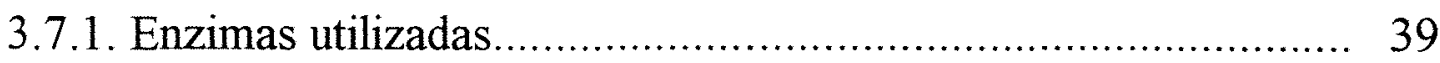


3.7.2. Determinação do efeito do tratamento enzimático sobre a capacidade floculante de $L$. fermentum em cultura mista ativa.

4. RESULTADOS E DISCUSSÃO.

4.1. Metodologias alternativas de contagem e cultura.

4.1.1. Metodologia de contagem por microplacas......................... 42

4.1.2. Meio alternativo de cultura ................................................ 44

4.2. Cultivo de L. fermentum em meio de cultura MCC ................... 45

4.3. Algumas características dos cultivos de L. fermentum e

S. cerevisiae.

4.4. Ensaios utilizando cultura mista.

4.4.1. Cultura mista ativa.

4.4.2. Cultura mista inativada por esterilização.

4.4.3. Comparação entre cultura mista inativada por esterilização e por antibacterianos

4.4.3.1. Cultura mista inativada por Kamoran $\mathrm{HJ}$ 56

4.4.3.2. Cultura mista inativada por penicilina $\mathrm{V}$ potássica. 56

4.4.3.3. Cultura mista ativa e inativada por esterilização. 58

4.5. Efeito do tratamento enzimático sobre a capacidade floculante de L. fermentum. 64

5. CONCLUSÕES. 74

REFERÊNCIAS BIBLIOGRÁFICAS. 76 APÊNDICE 89 


\section{LISTA DE FIGURAS}

Página

1 Micropipetador, ponteira e placas utilizadas nos plaqueamentos pela técnica de microplacas............................. 34

2 Técnica de cultivo de L. fermentum .................................. 37

3 Viabilidade celular da levedura $S$. cerevisiae nos tratamentos controle, cultura mista ativa e inativada por esterilização.

4 Viabilidade celular da levedura $S$. cerevisiae nos tratamentos controle, cultura mista ativa e inativadas por esterilização e pelos antibacterianos Kamoran HJ (HJ) e penicilina $\mathrm{V}$ potássiva $(\mathrm{PV})$

5 Avaliação do crescimento da levedura $S$. cerevisiae nos tratamentos controle, cultura mista inativada por esterilização, pelos agentes antibacterianos Kamoran $\mathrm{HJ}$ $(\mathrm{HJ})$ e penicilina V potássica (PV) e cultura mista ativa (S. cerevisiae em cultura mista ativa com L. fermentum), expressos em Log UFC/mL 63 
6 Determinação dos efeitos do tratamento enzimático sobre a floculação da levedura causada por L. fermentum, através de leituras espectrofotométricas, expressas em absorbância 69

7 Floculação da levedura $S$. cerevisiae causada por

L. fermentum $\left(\mathrm{x} 400^{(\mathrm{A})} \mathrm{e} \times 1000^{(\mathrm{B})}\right)$ 70

8 Efeitos da enzima papaína sobre a floculação da levedura $S$. cerevisiae causada por L. fermentum (x400) 71

9 Efeitos da enzima bromelina sobre a floculação da levedura S. cerevisiae causada por L. fermentum (x400). 72

10 Efeitos da enzima ficina sobre a floculação da levedura S. cerevisiae causada por L. fermentum $(\mathrm{x} 400)$. 73 


\section{LISTA DE TABELAS}

Página

1 Resultados das contagens de colônias de L. fermentum e $S$. cerevisiae, comparando as técnicas de semeadura em profundidade e microplacas

2 Crescimento de L. fermentum nos meios MRS-A e MCC-A, comparando a metodologia de semeadura em profundidade e microplacas.

3 Avaliação do desenvolvimento de L. fermentum em $\mathrm{MCC}$, medido através de análise turbidimétrica. 46

4 Desenvolvimento de L. fermentum em meio de cultura MCC-A

5 Acidez total, pH e população de L. fermentum em diferentes tempos, em meio MCC 
6 Resultados dos cultivos de L. fermentum e S. cerevisiae, antes da composição das partes que resultaram na cultura mista. 48

7 Viabilidade celular da levedura $S$. cerevisiae em presença de L. fermentum (cultura mista ativa). 50

8 Avaliação das populações inicial e final dos microrganismos nos ensaios com cultura mista ativa.

9 Viabilidade celular da levedura $S$. cerevisiae em presença de L. fermentum (cultura mista inativada por esterilização)

10 Avaliação das populações inicial e final dos microrganismos nos ensaios com cultura mista inativada por esterilização

11 Viabilidade celular da levedura S. cerevisiae em presença de L. fermentum, inativada por Kamoran HJ

12 Viabilidade celular da levedura $S$. cerevisiae em presença de $L$. fermentum inativada por penicilina $\mathrm{V}$ potássica 58 
13 Viabilidade celular da levedura $S$. cerevisiae em presença de L. fermentum em cultura mista ativa e inativada por esterilização

14 Determinação de acidez (g ácido láctico/L) e $\mathrm{pH}$ das culturas mistas ativa de $S$. cerevisiaee e inativadas por esterilização e pelos agentes antibacterianos Kamoran HJ e penicilina V potássica. 64

15 Viabilidade celular da cultura da levedura S. cerevisiae com a adição de enzimas do grupo peptidohidrolases. 65

16 População de L. fermentum após a adição das enzimas papaína, bromelina e ficina 


\title{
VIABILIDADE CELULAR DE Saccharomyces cerevisiae EM CULTURA MISTA COM Lactobacillus fermentum
}

\author{
Autora: Rosana Maria de Oliveira Freguglia \\ Orientador: Prof. Dr. Jorge Horii
}

\section{RESUMO}

A fermentação alcoólica em meio de caldo de cana-de-açúcar freqüentemente sofre contaminação por bactérias lácticas, entre as quais Lactobacillus fermentum, cuja espécie pode apresentar linhagens que possuem a propriedade de causar floculação em leveduras, agregando um elevado número de células à sua volta pela ação de seus componentes, um dos quais provavelmente de caráter protéico. A interação bactéria, levedura e o meio sobre a viabilidade celular da levedura são ainda pouco esclarecidas.

Este trabalho teve como objetivo verificar o comportamento da viabilidade celular da levedura quando em cultura mista com L. fermentum, observando influências das condições do meio e de produtos metabólicos. 
Os microrganismos $S$. cerevisiae e L. fermentum foram cultivados individualmente em meio de caldo de cana suplementado com extrato de levedura e peptona. Com a mistura de ambas as culturas foram avaliados a viabilidade celular da levedura e o crescimento em ensaios divididos em: cultura mista ativa, cultura mista inativada por esterilização e cultura mista inativada por agentes antibacterianos (Kamoran $\mathrm{HJ}$ e Penicilina V potássica). Nos cultivos onde foram observadas floculação, testou enzimas do grupo peptidohidrolases (papaína, bromelina e ficina) para avaliar o efeito destas sobre a floculação.

A viabilidade celular utilizando cultura mista ativa apresentou reduções de cerca de $96 \%$ em 12 horas demonstrando a influência da presença da bactéria sobre a viabilidade. Nos ensaios com culturas inativadas, as reduções da viabilidade celular foram em torno de 50 a $60 \%$ nas primeiras 12 horas, chegando a $90 \%$ com 24 horas de cultivo, demonstrando a influência somente dos produtos metabólicos sobre a viabilidade de Saccharomyces cerevisiae. Quando da utilização das enzimas, foi observado ação desfloculante promovida pela papaína, bromelina e ficina, ainda não relatados, sobre a floculação de $S$. cerevisiae causada por L. fermentum, confirmando a natureza protéica do causal deste efeito. 


\section{CELLULAR VIABILITY OF Saccharomyces cerevisiae IN MIXED CULTURE WITH Lactobacillus fermentum}

Author: Rosana Maria de Oliveira Freguglia Adviser: Prof. Dr. Jorge Horii

\section{SUMMARY}

The alcoholic fermentation in sugar cane juice frequently has contamination by lactic bacteria, among there $L$. fermentum specie can have strains that have the capacity of causing yeasts flocculation in yeast, by bringing together a hight elevated number of yeast cells around then by the action of its components being one of them of protein nature. The aim of this work was to study the cellular viability of the yeast $S$. cerevisiae in mixed culture with $L$. fermentum, considering the growing conditions and bacterial metabolic products. The microorganisms were cultivated individually in sugar cane juice supplemented with yeast extract and peptone. Yeast viability was investigated in mixed culture with active bacterial culture and with inactivated bacterial culture (by heat sterilization or by addition of antibacterial agents. Deflocculation tests performed on yeast flocculated cultures using peptidohydrolases group enzymes (papain, bromelin and ficin). 
In mixed active culture yeast viability reduction of $96 \%$ was noticed after 12 h. In assays using the inactivated bacterial culture reduction were between 50 to $60 \%$ during the first $12 \mathrm{~h}$, and reaching $90 \%$ after $24 \mathrm{~h}$. It was observed the influence of bacterial metabolic products on yeast viability. It was also observed a deflocculation ability of papain, bromelin and ficin not yet described, confirming the protein involvement in the floc formation by $L$. fermentum. 


\section{INTRODUÇÃO}

Os prejuízos causados pela contaminação bacteriana em processos fermentativos tem início na lavoura com a matéria-prima. A cana-de-açúcar contaminada, aliada aos problemas de eficiência no tratamento do caldo leva um grande número de bactérias e produtos de seu metabolismo para a fermentação (Amorim \& Oliveira, 1982; Kaji \& Canhos, 1989).

Dentre os muitos problemas causados pela contaminação bacteriana na fermentação, podemos citar: queda de viabilidade da levedura, aumento de acidez do vinho, queda de rendimento fermentativo, queda da produtividade, entre outros.

Levantamentos sobre estes contaminantes apontam que cerca de $60 \%$ das espécies bacterianas encontradas nas dornas de fermentação pertencem ao gênero Lactobacillus (Rodini, 1985; Rosales, 1989; Gallo, 1990; Gallo \& Canhos, 1991; Gallo, 1992), sendo a espécie L. fermentum citada como a mais freqüente (Gallo, 1990).

As linhagens de L. fermentum vem sendo referidas como as responsáveis pelos problemas de floculação da fermentação (Yokoya \& OlivaNeto, 1991), porém, a interação bactéria-levedura e o meio de cultura é ainda pouco conhecida, principalmente com relação a influência da bactéria e as transformações do meio sobre a viabilidade celular da levedura. 
Com base no exposto, o presente trabalho teve por objetivo avaliar o comportamento da viabilidade celular de Saccharomyces cerevisiae quando em culturas mistas com Lactobacillus fermentum, observando influências das condições do meio e de produtos metabólicos. 


\section{REVISÃO DA LITERATURA}

\subsection{Contaminantes do processo de produção de álcool}

Os contaminantes são microrganismos, habitantes naturais das plantas, do solo, matéria orgânica em decomposição e podem estar associados as pragas e moléstias da cultura. Diferentes espécies de microrganismos podem aparecer nas várias etapas do processo de produção de álcool mas, de alguma maneira, todos acarretam prejuízos durante este processamento.

\subsubsection{Matéria-prima}

Desde o momento que se queima a cana até a clarificação do caldo extraído, os açúcares estão expostos à ação enzimática competidora de um grande número de microrganismos. Estes microrganismos do ar e do solo, aderem a cana, juntamente com as impurezas trazidas com o carregamento. Não se sabe se estes organismos são selvagens, ou epífitos da planta, segundo Honig (1969). Sobre a cana queimada, o autor cita ainda que a demora de 7 a 8 dias para a moagem após a queima leva a uma queda de pureza na faixa de 4,2 a $5,9 \%$.

Bevan \& Bond (1971) estudando bactérias desde a cana verde até a fábrica, isolaram microrganismos dos gêneros Saccharomyces, Torula $e$ 
Pichia, bacilos do solo, principalmente Bacillus cereus, Pseudomonas, Streptomyces produtores de ácidos e, bolores do tipo ascomicetos; constataram ainda que todos metabolizam açúcar rapidamente e são resistentes à temperatura de $50-55^{\circ} \mathrm{C}$. Das rachaduras provocadas pelo crescimento do colmo foram isolados cocos principalmente pertencentes ao gênero Leuconostoc, espécies de Saccharomyces, grande variedade de fungos e alguns bastonetes produtores de ácidos. Os autores citam ainda que a queima da canade-açúcar eleva a temperatura do colmo a $55-85^{\circ} \mathrm{C}$ e, aparentemente, não destrói muitas das bactérias esporogênicas termossensíveis, uma vez que as mesmas tem sido encontradas minutos após a queimada $e$, as altas temperaturas atingidas removem a cera do colmo que parece apresentar função bacteriostática.

Silva (1974) cita que fatores como variações na forma de colheita, terrenos muito variados, diferentes variedades de cana, condições climáticas muito oscilantes, pragas e doenças, tipos de transporte, armazenamento, tempo decorrido entre o corte e o processamento de cana-de-açúcar, estado da matéria prima ao dar entrada na usina contribui significativamente na carga microbiana da cana-de-açúcar.

Além do problema de contaminação pelo ar e pelo solo, as rachaduras dos colmos e perfurações causadas por pragas também expõem a cana a ação de microrganismos. Sobre o complexo broca/podridão Lopes et al (1983), mencionaram que pelos orifícios abertos pela broca penetram microrganismos produtores de enzimas específicas que atuam sobre a sacarose, degradando-a em outras formas de açúcares, sendo em parte, consumidos como energia responsável pelas atividades microbianas. 
Segundo Stupiello (1993), mesmo que nem todas as espécies de microrganismos encontradas na obtenção da matéria-prima estejam presentes durante outras etapas do processo, estes são de grande importância no que se refere a perdas de açúcares e, portanto, queda do rendimento industrial, assim como formação de produtos que poderão ocasionar problemas operacionais.

\subsubsection{Processamento da matéria-prima}

As perdas de sacarose no campo e a contaminação levada para a indústria tem sido freqüentemente estudadas, inclusive gerando polêmicas a respeito de tempo entre transporte/industrialização, corte mecânico ou manual, queima ou não da cana-de-açúcar. Delgado (1985) aponta como um dos problemas causados no processamento de canas cruas ou queimadas, depois de 48/72 horas, o aumento da taxa de microrganismos devido a ocorrência de exsudação de caldo na superficie do colmo, predispondo os mesmos a uma deterioração. Quanto ao corte da cana, Kaji \& Canhos (1989) ressaltam que o tipo de processo utilizado na colheita de cana-de-açúcar pode propiciar o aumento do nível de deterioração em decorrência dos danos físicos causados a planta. A colheita mecanizada, feita por colheitadeiras que provocam seccionamento do colmo em toletes curtos, causam o aumento do grau de infecção e conseqüentemente a deterioração tem início aproximadamente uma hora e meia após o corte. Os microrganismos predominantes são: leveduras, Leuconostoc, Xanthomonas e Aerobacter. Foi constatado que, após 4 dias de corte pode haver uma perda de açúcar de até $28 \%$, sendo a perda maior nos toletes pequenos. 
A deterioração da cana colhida mecanicamente é mais rápida do que a colhida de forma manual; a cana não queimada, cortada e despalhada se constitui em uma ótima matéria prima para a indústria. A queima das folhas diminui as impurezas vegetais e facilita o corte mas não reduz o nível de microrganismos.

Tilbury (1975) estudou o efeito da estocagem no crescimento de bactérias lácticas, mostrando que, até o $4^{\circ}$ dia níveis de $10^{7}$ a $10^{8}$ bactérias $/ \mathrm{mL}$ são alcançados, predominando Leuconostoc mesenteroides e Leuconostoc dextranicum e, a partir daí, provavelmente devido a queda de $\mathrm{pH}$, passaram a ser encontrados Lactobacillus.

O aumento do tempo de armazenamento da cana contribui para as perdas de açúcar devido a atividade dos microrganismos, principalmente das bactérias lácticas. Por outro lado, pode ocorrer acréscimo no teor de fibras com a eliminação de água do caldo através da respiração e da transpiração com reflexos negativos na extração dos açúcares (Kaji \& Canhos, 1989).

Avaliando alguns dos pontos críticos do processo de fabricação de açúcar e álcool, podemos citar a água de lavagem de cana como um fator importante quando nos referimos a contaminação. Segundo Boletim Copersucar (1983), a água de lavagem de cana quando mantida a $\mathrm{pH}$ na faixa de 10-11, tem sua contagem microbiana em nível baixo, nos circuitos fechados. A ineficiência no controle do $\mathrm{pH}$ resulta em um aumento significativo das contagens, principalmente quando este atinge níveis abaixo da neutralidade. A influência da contaminação de microrganismos da água de lavagem de cana sobre a população microbiana do caldo misto não foi claramente detectada, entretanto, observa-se que, quando há controle eficiente de $\mathrm{pH}$, a contagem total de microrganismos no caldo misto se mantém em 
níveis inferiores a $10^{7}$ por mililitro. Com relação ao processo de extração do caldo, os autores do referido boletim citam que, nos equipamentos de extração, há sempre focos de crescimento de bactérias lácticas, pois, amostras retiradas após o trajeto do caldo (caixas, peneiras, tubulações) próximas a sulfitação, calagem ou do tratamento térmico, apresentam contagens superiores a do caldo misto, ocorrendo também ligeiro abaixamento de $\mathrm{pH}$.

O caldo da cana se constitui em um ótimo substrato para o crescimento de microrganismos, face aos teores de nutrientes orgânicos e inorgânicos que apresenta, alta atividade de água, $\mathrm{pH}$ e temperatura favoráveis. Assim, uma ampla e variada microbiota bacteriana encontra-se normalmente presente no mosto utilizado como matéria prima para a produção de açúcar e do álcool (Gallo \& Canhos, 1991).

São muitos os estudos sobre a avaliação de contaminantes na extração do caldo (Honig, 1969; Lima et al, 1974; Tilbury, 1975; Tilbury et al, 1977; Boletim Copersucar, 1983) sendo isolados microrganismos infectantes em diversas partes do processo. Nestes levantamentos, foi constatado a predominância das bactérias lácticas, devido as suas características acidofilicas e de tolerância a soluções ricas em açúcares. Além disso, muitas espécies produzem polissacarídeos capsulares que excretam gomas extracelulares que protegem as células dos efeitos letais como aquecimento e produtos químicos. Dessa forma, as bactérias lácticas podem sobreviver nas diferentes etapas do tratamento do caldo de cana (Lima et al, 1974; Boletim Copersucar 1983).

O caldo da cana-de-açúcar é considerado de má qualidade quando o $\mathrm{pH}$ decresce substancialmente devido a provável formação de ácido acético e láctico, aumento de goma, aumento de açúcares redutores. A formação de 
gomas pode acarretar problemas operacionais nas usinas de açúcar e de álcool tais como entupimentos em canalizações, bombas e centrífugas (Lima et al, 1974; Amorim \& Oliveira, 1982), bem como dificuldades na clarificação, evaporação e cristalização do açúcar (Lima et al, 1974; Boletim Copersucar 1983).

Nos caldos provenientes da moagem, com baixo $\mathrm{pH}$, há crescimento de microrganismos acidófilos como Leuconostoc e Lactobacillus (Tilbury, 1975). As condições de $\mathrm{pH}$ e temperatura de cada etapa da fermentação alcoólica irão selecionar o desenvolvimento particular de cada espécie de microrganismo. Com a contaminação temos, como maior prejuizo, a degradação da sacarose e a formação dos ácidos láctico e acético, pois há perda do açúcar disponível e “intoxicação" das leveduras pelos metabólitos formados (Frederick, 1994).

\subsubsection{Fermentação alcoólica}

A fermentação alcoólica consiste na transformação dos açúcares do mosto em etanol, gás carbônico e energia, sob ação enzimática das leveduras. Quando condições de temperatura, acidez, concentração de açúcares, qualidade da cana, higiene, preparação de pé-de-cuba e do mosto são impróprias podem desenvolver-se outros tipos de microrganismos que consomem os açúcares ou então o álcool, produzindo compostos orgânicos indesejáveis para a qualidade final do álcool, além de reduzir o rendimento do processo (Camargo et al, 1990).

Serra et al (1979) em trabalhos desenvolvidos em uma usina de açúcar e álcool, observaram que a principal característica da contaminação da fermentação alcoólica é a formação de pequenos flocos compostos por células 
de levedura e bactéria, cuja formação ocorre no mosto em fermentação. No fermento separado pelas centrífugas, é mais acentuado e visivel este fenômeno. A adição de ácido sulfúrico durante o tratamento do fermento, provoca a separação das células aglomeradas, desfazendo os flocos e liberando a bactéria infectante, a qual não é destruída, mesmo a pH 1,9-2,0. Antes da adição de ácido foram detectados várias espécies de Bacillus no fermento mas apenas uma, relatada como Sporolactobacillus sp resistiu ao tratamento sendo apontada como agente causal.

Serra et al (1980), avaliando condições de controle de fermentação determinaram que a correlação positiva entre leveduras vivas e rendimento mostra a necessidade de controle sobre os fatores que influem sobre sua quantidade na dorna de fermentação e sobre fatores que mantém a sua viabilidade: temperatura de fermentação, nutrição mineral da levedura, tensão de oxigênio, teor alcoólico do meio, $\mathrm{pH}$ do meio, quantidade de inóculo em termos de leveduras vivas, e outros.

Gallo (1989) cita que as próprias condições de cada etapa do processo de produção de álcool selecionam o desenvolvimento de microrganismos.

Segundo Gutierrez et al (1991) diversos compostos podem estar presentes ou serem formados ou ainda adicionados a um mosto de caldo de cana ou xarope ou ainda serem produzidos durante a fermentação e assim, de alguma forma, afetar a levedura durante o processo fermentativo. Dentre esses compostos podem ser citados: acetaldeído, ácido acético e láctico, ácidos graxos de cadeia curta, etanol, furfural, hidroxi-metil-furfural, nitrito, níquel, sulfito, tanino, etc. Os autores citaram que os ácidos acético e láctico podem ser formados por bactérias contaminantes e leveduras. 
No processo de obtenção de etanol pela via fermentativa, é necessário no início do processo, estimular a formação de massa celular em detrimento da produção de etanol para se obter rapidamente a quantidade de fermento que se situa em torno de 10 a $15 \%$ em volume de vinho, porém, o contínuo aumento da quantidade de células não é desejável porque reduz a eficiência da fermentação alcoólica (Gutierrez, 1991).

Alcarde (1995) cita em seu trabalho que um dos grandes problemas que vêm ocorrendo durante o processo de produção de álcool é a sobrevivência de microrganismos após o tratamento térmico e a recontaminação do mosto desde a saída do decantador, passando pelos trocadores de calor, até a chegada às dornas de fermentação, onde há um aumento da população bacteriana que chega a atingir centenas e até milhares de vezes.

Amorim \& Oliveira (1982) referem-se às bactérias pertencentes aos gêneros Acetobacter, Lactobacillus, Bacillus, Clostridium, Enterobacter, Leuconostoc e Streptococcus como sendo as mais atuantes e geralmente associadas com fracassos da fermentação alcoólica devido a formação de ácido láctico e de outros ácidos orgânicos. Os autores estabelecem uma correlação entre ácidos do vinho e queda no rendimento alcoólico, sendo encontrados os rendimentos mais baixos $(60 \%)$ para valores de acidez entre 5 a $6 \mathrm{~g} / \mathrm{l}$. Também mencionam a importância dos bastonetes na infecção, afirmando que quanto maior a porcentagem destes no total de bactérias, menor o rendimento da destilaria.

$A$ indústria sucro-alcooleira sofre $\mathrm{o}$ efeito do crescimento de contaminantes que causam perdas de açúcar ou desviam para outros compostos em lugar do etanol. Esses compostos representam prejuízos no 
rendimento industrial, podendo também causar problemas de ordem operacional ou inibir a levedura produtora de etanol (Oliva-Neto, 1995).

Durante a fermentação alcoólica o etanol produzido também pode exercer efeito inibitório sobre a levedura e levar a quedas de viabilidade. Avaliando a influência da produção e acúmulo de etanol sobre a viabilidade de Saccharomyces cerevisiae em fermentações rápidas, Nagodawithana \& Steinkraus (1975) determinaram que este pode exercer um efeito letal sobre as células devido ao teor alcoólico $(12 \% \mathrm{v} / \mathrm{v})$. Esta queda na viabilidade da levedura se acentuou durante a fase logarítmica de crescimento.

Em estudos sobre cinética de fermentação alcoólica, Leão \& Uden (1982) e Namba et al (1987) citaram que, durante a fermentação por $S$. cerevisiae, o acúmulo de etanol levou a uma inibição no crescimento celular, queda da viabilidade celular; fatores que afetaram o consumo de açúcar e a produção de etanol.

O efeito letal sobre Saccharomyces cerevisiae foi estudado por Gilliland \& Lacey (1964), que verificaram a influência do ácido acético na inibição do crescimento e queda da viabilidade celular quando em cultura com Acetobacter. Este mesmo efeito foi observado pelos autores em leveduras do gênero Pichia, Schizosaccharomyces, Zygosaccharomyces, Torula, Candida e em algumas espécies de Saccharomyces.

Kaneko \& Yamamoto (1968) fizeram referência a atividade antilevedura exercida por alguns contaminantes, entre eles Acetobacter. Em seu trabalho, utilizando leveduras cultivadas em meio de maltose, apontaram um efeito letal exercido pela introdução de bactérias produtoras de ácido acético.

Alterthum et al (1984) utilizaram a técnica de reciclagem de células na produção de etanol descrevendo a perda de rendimento alcoólico nas 
fermentações contaminadas por bacilos e cocos como sendo o mais grave problema e responsável também pela morte da levedura. Os autores citaram ainda que a elevada porcentagem de leveduras mortas, bem como o aumento da acidez do mosto, mostra a provável liberação de substâncias tóxicas ao meio de cultura pelas células bacterianas, promovendo a morte da levedura ou dificultando seu desenvolvimento.

Rosales (1989) isolou microrganismos de amostras de fermento centrifugado, fermento tratado industrialmente com ácido sulfúrico, mosto, vinho inicial e vinho final provenientes de usina de açúcar identificando as seguintes bactérias como contaminantes do processo: Lactobacillus $s p$ (45,04\%), Leuconostoc mesenteroides (14,41\%), Bacillus sp (9,46\%), Acetobacter sp $(7,21 \%)$, Enterobacter $s p(6,75 \%)$, Sporolactobacillus $s p$ $(3,60 \%)$, Micrococcus varians (1,80\%), Staphilococcus sp $(1,35 \%)$, Pseudomonas fluorescens (1,35\%), Escherichia coli (1,35\%) e Citrobacter $s p(0,50 \%)$ determinando a predominância das bactérias lácticas no processo de fermentação alcoólica.

Comprovando estes resultados, em trabalho realizado utilizando como substrato mosto e vinho de fermentação, Gallo (1990) constatou a predominância de bactérias gram positivas $(98,52 \%)$, de bastonetes $(87,76 \%)$ e de não esporulados $(73,95 \%)$. O gênero Lactobacillus aparece como o mais freqüente $(59,75 \%)$, sendo as espécies encontradas: L. fermentum $(15,04$ $\%)$, L. helveticus $(14,08 \%)$, L. animalis $(4,55 \%)$, L. buchneri $(3,76 \%)$, L. acidophilus $(3,07 \%)$, L. vitulinus $(2,96 \%)$, L. viridescens $(2,35 \%), L$. amilophilus $(1,88 \%)$, L. agilis $(1,25 \%)$, L. reuteri $(1,22 \%)$, L. delbruechii subsp. lactis (1,04\%), L. murinus (1,02\%), L. delbruechii subsp. bulgaricus $(0,71 \%)$, L. coryniformis subsp. torquens $(0,71 \%)$ e L. sake $(0,42 \%)$. 
Os efeitos de alguns contaminantes e seus produtos metabólicos sobre a levedura são ainda pouco conhecidos, porém sabe-se que um nível elevado de contaminação pode causar redução na produtividade e no rendimento fermentativo pela competição por substrato, redução da vitalidade das células de levedura pela "intoxicação" por metabólitos do agente contaminante e floculação das leveduras pela ação das células bacterianas (Yokoya, 1989).

\subsection{Bactérias produtoras de ácido láctico}

As citações com referência às bactérias produtoras de ácido láctico tem por objetivo relacionar algumas de suas características e aspectos sobre a influência de seu produto metabólico sobre a fermentação alcoólica.

\subsubsection{Algumas características das bactérias lácticas}

Breed et al (1957) apresentam as bactérias lácticas como duas famílias distintas: Lactobacilaceae, contendo o gênero Lactobacillus que são caracterizadas por bactérias em forma de bastonetes gram positivo, geralmente imóveis, catalase negativa e anaeróbicos facultativos; a família Streptococcaceae, onde estão incluídos os gêneros Streptococcus, Pediococcus, Leuconostoc, caracterizados morfologicamente por cocos em cadeias, em tétrades e em pares, respectivamente.

Galli (1961) cita que a fermentação láctica é produzida por um grande número de bactérias, sendo a maioria pertencente à família Lactobacillacea. A fermentação láctica se desenvolve em mosto ligeiramente ácido, próximo da neutralidade, sendo a acidez excessiva desfavorável ao seu desenvolvimento. 
Geralmente ocorre a temperaturas relativamente elevadas, por exemplo, o Streptococcus lactis e o Lactobacillus casei a 30-35 ${ }^{\circ} \mathrm{C}$, o Lactobacillus debrueckii e o Lactobacillus bulgaris a $40-45^{\circ} \mathrm{C}$ ou mais.

Demeter (1969) estudando as bactérias acidolácticas e suas propriedades fermentativas, sugere a divisão em 03 gêneros: termófilos homofermentativos (Thermobacterium), mesófilos homofermentativos (Streptobacterium) e bacilos heterofermentativos (Betabacterium), com base no desenvolvimento, sensibilidade a diversas temperaturas, sensibilidade a $\mathrm{pH}$ e resistência a sais que apresentaram as bactérias lácticas.

Segundo Lima et al (1975), também citado por Figueiredo (1989), os Lactobacillus são bactérias não patogênicas, imóveis, gram positivas, não esporuladas, crescem em pH 5,5 a 6,0, catalase negativa. Em relação ao metabolismo de carboidratos são consideradas sacarolíticas, podendo ser diferenciadas pelo metabolismo fermentativo em: homofermentativa, que são as mais importantes e com grande interesse para a fabricação de ácido láctico; heterofermentativas que, terminada a fermentação láctica, produzem $\mathrm{CO}_{2}$, etanol e ácido acético, além do ácido láctico.

Bioquimicamente, as bactérias lácticas não possuem o ciclo de Krebs e a cadeia respiratória clássica, o que as limita a ambientes de baixa concentração de oxigênio (microaerofilia), ou mesmo ausência total (BryanJones, 1975).

Serra et al, (1979) descreveram as bactérias lácticas como sendo gram positivas, responsáveis pela fermentação láctica e que podem ser heterofermentativas, onde produzem, além do ácido láctico, outros metabólicos como ácido butírico, ácido fórmico e ácido acético, etanol e $\mathrm{CO}_{2}$ : ou homofermentativos que produzem somente ácido láctico. 
Oliveira et al (1996) citaram em seu trabalho, características morfológicas e citológicas de algumas bactérias isoladas do processo de produção de açúcar e de álcool e referem-se ao L. fermentum como sendo bastonetes de 0,5 a $0,9 \mu \mathrm{m}$ de largura e comprimento muito variável que aparecem isolados e/ou aos pares, gram positivos, não esporulados e raramente com motilidade. Segundo os autores esta bactéria apresenta as seguintes características fisiológicas: são anaeróbias facultativas, heterofermentativas, apresentam catalase negativa, temperatura entre 15 e $45^{\circ} \mathrm{C}$, tendo como ótimo entre 30 a $40^{\circ} \mathrm{C}$, pH ótimo na faixa de 5,5 a 5,9 .

Klaenhamner (1984) estudando genética de lactobacilos, citou que o pouco progresso quanto ao conhecimento da genética deste gênero está relacionado a dificuldade em realizar a lise celular com lizozima e ao desenvolvimento de procedimentos confiáveis para o isolamento de DNA plasmidial. Ainda assim tem sido descritos DNA plasmidial de L. acidophilus, L. reuteri, L. casei, L. fermentum e L. helveticus, sendo que sua deteç̧ão tem sido limitada a um número selecionado de linhagens de cada espécie. Isto demonstra a ineficiência dos métodos usuais para esse gênero. Algumas propriedades funcionais de plasmídeos em lactobacilos descritas por Mckay, $1983^{1}$ e citada por Frederich, 1994, relacionam utilização de lactose, resistência a bacteriofágos, produção de bacteriocinas, atividade de proteinases, etc....A autora cita que algumas dessas características e sua associação com plasmídeos são altamente especulativas baseando-se apenas na perda fenotípica de uma propriedade metabólica.

${ }^{1}$ MCKAY, L. Funcional properties of plasmids in lactic streptococci.. Antonie Van Leuwenhoek, 1983. v. 49, p. 259-274. 
A produção de bacteriocinas, substância antimicrobiana de natureza protéica, é uma característica genética bastante difundida às bactérias lácticas. Estas bacteriocinas produzidas pelas bactérias lácticas possuem um efeito bactericida que diminui rapidamente células viáveis em cultivo após alguns minutos de tratamento. Seu efeito letal é maior na fase logarítmica do que na estacionária (Santos et al, 1994). As bacteriocinas, em forma nativa, produzidas por diversos Lactobacillus sp. tendem a formar agregados protéicos de um peso molecular de 100.000 a 300.000 Daltons que dissociam por ultrafiltração, com tratamento com S.D.S, com uréia ou com diversos detergentes (Muriana \& Klaenhammer, 1991).

$\mathrm{O}$ espectro antimicrobiano das bacteriocinas parece estar associado à presença de receptores apropriados nos microrganismos sensíveis, entretanto a maioria das bacteriocinas produzidas pelas bactérias gram negativas atuam fundamentalmente sobre espécies microbianas relacionadas taxonomicamente com elas, enquanto que as bacteriocinas das gram positivas são antagonistas de uma grande diversidade de espécies gram positivas (Tagg et al, 1976).

\subsubsection{Influência da contaminação por bactérias lácticas na fermentação}

Bryan-Jones (1975) em seu estudo sobre determinação de bactérias produtoras de ácido láctico na fermentação de destilados de malte, isolou e quantificou as seguintes bactérias: Lactobacillus fermentum, L. brevis, $L$. delbrueckii, L. plantarum, L. casei, Leuconostoc sp, Streptococcus lactis e Pediococcus cerevisiae. Na determinação do número de colônias e no acompanhamento do desenvolvimento das bactérias lácticas, o autor utilizou o 
meio de cultura MRS agar e a técnica de gota nos plaqueamentos que adaptou do método descrito por Sharpe e Kilsby (1971). Na avaliação desta metodologia adaptada, não houve diferenças significativas entre os resultados obtidos quando comparada a técnica convencional de plaqueamento em profundidade.

A presença de bactérias lácticas na fermentação tanto na forma de cocos como de bastonetes causam, segundo Yokoya (1991), aumento na acidez do vinho pela produção de ácidos láctico e acético, e acarretam quedas na percentagem de células vivas das leveduras e do rendimento alcoólico; as temperaturas superiores a $34{ }^{\circ} \mathrm{C}$ favorecem o crescimento das formas em bastonetes.

A ação inibitória de ácidos orgânicos sobre a levedura depende de vários fatores tais como: tipo e concentração do ácido e das leveduras, sinergismo com outros produtos e pressão osmótica do meio (Oliva-Neto, 1995).

Oliva-Neto (1990) avaliando a influência da contaminação por bactérias lácticas na fermentação concluiu que a acidez total no vinho esta inversamente correlacionada com a relação levedura/bactéria e diretamente correlacionada com o número de células de bactérias lácticas, até um certo limite, a partir do qual, o aumento do número de bactérias lácticas e a diminuição da relação levedura/bactéria não correspondem mais ao aumento da acidez total. Ainda, determinou que em concentrações superiores a 4,8 g/l no vinho, expressas em ácido láctico, há uma correlação inversa entre a acidez e a relação entre os brotos de leveduras vivos e mortos, e entre acidez e viabilidade de leveduras. 
Durante a fermentação as células de levedura tem seu metabolismo e crescimento inibidos pelo efeito de altas concentrações de ácido láctico (Makanjiola, et al 1992). Com relação aos subprodutos presentes nos processos de fermentação alcoólica, Maiorella et al (1983) concluíram que altas concentrações de ácido láctico (10-40 g/L) podem levar a uma inibição de crescimento de $S$. cerevisiae, causando uma redução da massa de célula de até $80 \%$.

Chin e Ingledew (1994) avaliando o efeito de bactérias produtoras de ácido láctico em fermentação de bebidas destiladas, observaram que após 5 fermentações há um aumento gradual do teor de ácido láctico levando a redução de cerca de $60 \%$ na viabilidade da levedura.

Oliva-Neto 1995, estudando técnicas de cultivo de população mista de leveduras e bactérias lácticas, determinou que, quando testadas em condições físico-químicas similares às obtidas na indústria e com altas concentrações de bactérias, é possível simular o crescimento da população bacteriana durante a fermentação alcoólica. Este crescimento parece não ser tão dependente do tamanho da população mas sim das condições físico-químicas e, principalmente, dos nutrientes presentes no meio de cultivo.

\subsection{Floculação de leveduras}

A floculação de leveduras foi descrita por Pasteur em 1876, observada em leveduras produtoras de cerveja e foi o primeiro sistema de agregação de células estudado (Calleja, 1987).

O termo floculação é usado para designar o fenômeno reversível de agrupamentos de células que comumente se manifesta no final da fase 
exponencial de crescimento ou na fase estacionária (Calleja e Johnson, 1977). Segundo os autores, são consideradas células livres os agrupamentos de até 10 células. Stratford (1996) relaciona a floculação de leveduras à agregação de células formando flocos. $\mathrm{O}$ autor citou que este fenômeno pode ser considerado favorável para alguns processos fermentativos industriais como cervejarias, pois estes flocos podem ser separados do vinho por decantação ou flotação.

A agitação também é considerada um fator importante para a floculação. A agitação aumenta a floculação pelo aumento da probabilidade de colisão entre as partículas mas também pode levar a uma quebra dos flocos levando a um estado de equilibrio, o que vai depender da linhagem, do sistema e velocidade de agitação (Stratford \& Keenan, 1988).

A floculação em levedura pode ser causada devido a presença de linhagens de levedura geneticamente floculantes as quais se agregam para formar flocos que sedimentam (Stratford \& Keenan, 1988). A floculação em leveduras pode ser considerada como um mecanismo de sobrevivência (Stratford 1992b).

Bromberg (1994) relacionou alguns modelos para esclarecer o mecanismo do processo de floculação, entre eles o modelo coloidal, o modelo de pontes de cálcio, o modelo das lectinas e o modelo simbiótico. 
O modelo coloidal relaciona a floculação com fenômenos de agregação de partículas. Os colóides podem ser rapidamente agregados pela neutralização da carga da superfície, pela adição de sal ou pela mudança de $\mathrm{pH}$, e pode se relacionar com o início do processo de floculação (Shaw, $1975^{2}$ citado por Bromberg, 1994; Stratford et al 1992b). Segundo a autora, este modelo não considera o requerimento específico por íons cálcio, característica apresentada por muitas linhagens de leveduras.

O modelo das pontes de cálcio descrito por Mill (1964) foi baseado em princípios físico-químicos onde íons de cálcio formariam pontes entre sítios receptores da superficie de duas células. Estas ligações seriam estabilizadas por pontes de hidrogênio entre carboidratos da parede das células envolvidas.

Segundo Santos (1991), a teoria das pontes de cálcio entre proteínas das paredes de células adjacentes propõe um mecanismo não específico para superar a repulsão eletrostática provocada pelas superfícies celulares carregadas negativamente.

Nishihara et al (1982) estudaram a inibição da floculação de leveduras por agentes quelantes como EDTA, cuja atividade inibitória só era revertida pela adição de ións cálcio e também pela inibição por outros íons como sódio, bário, estrôncio, que são competitivamente superadas pela adição de cálcio.

Com relação ao modelo das lectinas, Stratford (1996) define a floculação de leveduras como um processo reversível, não sexual, mediado por lectinas cujas células podem ser dispersas por agentes quelantes ou açúcares simples.

${ }^{2}$ SHAW, D. J. Introdução a química dos colóides e de superfícies. São Paulo. Edgard Blütcher, 1975. $185 \mathrm{p}$. 
As proteínas do tipo lectinas vem sendo relacionadas à fenômenos de agregação microbianos; são comumente encontradas nas superficies celulares desempenhando um papel importante nos processos de interação e de reconhecimento celular (Sharon, $1987^{3}$ citado por Bromberg, 1994).

Segundo Miki et al, $1982^{4}$, citado por Santos (1991), as células floculantes possuiriam moléculas protéicas tipo lectinas que se ligariam a resíduos das mananas de células adjacentes, sendo que os íons poderiam agir como cofatores na ativação da capacidade ligante dos componentes protéicos.

Este modelo considera apenas que as células floculantes possuem proteínas ligantes, enquanto que os receptores de açúcares para a floculação são encontrados tanto nas células floculantes como nas não floculentas. Não foram relatados efeitos inibitórios de sais sobre os receptores de células nãofloculentas mas as linhagens floculentas se mostraram incapazes de flocular devido a inibição por sais tais como sódio e magnésio (Nishihara et al, 1982).

$\overline{3}$ SHARON, N. Bacterial lectins, cell-cell recognition and infections disease. FEBS Lett, v. 217, n. 2, p, $145-157.1987$.

${ }^{4}$ MIKI, B. L. A.; POON, N. H.; JAMES, A. P.; SELIGY, V. L. Possible mechanism for flocculation interactions governed by gene FLO 1 in Saccharomyces cerevisiae. J. Bacterial,. v. 150, n. 2 , p. $878-889.1982$ 
O modelo simbiótico sugere a adesão entre diferentes tipos de células, como por exemplo de leveduras por outros microrganismos geralmente bactérias (Harris \& Michell, $1973^{5}$ citado por Bromberg 1994; Stratford 1992b). As interações celulares podem ser causadas por substâncias floculantes, lectinas e fimbrias ou outros compostos. A participação de proteínas na floculação tem sido verificada através do tratamento com agentes desnaturantes e proteases como papaína, tripsina, quimiotripsina e pepsina, causando perda total ou parcial da floculação (Nishihara et al 1982). Os mesmos autores citaram que outras enzimas como lipase e lizozima não apresentam tal efeito.

Bromberg (1994) em sua revisão citou aspectos que envolvem o processo de floculação e relaciona os fatores ambientais e efeitos envolvidos, agrupando-os em efeitos físicos (agitação, temperatura), efeitos químicos ( $\mathrm{pH}$, íons, solventes orgânicos, substâncias nitrogenadas) e efeitos biológicos (concentração microbiana inicial, formação de flocos, interação entre diferentes microrganismos em uma cultura mista, Esser \& Küts, 19836)

HARRIS, R. H. \& MITCHELL, R. The role of polymers in microbial aggregation. Ann. Rev. Microbiol. 1973. v. 27, p. 27-50.

6 ESSER,K \& KÜTS, U. Flocculation and its implication for biotechnology. Proc. Biochem. 18, dez. 1983. 21-23 p. 


\subsection{Floculação de leveduras causada por bactérias}

A floculação da levedura pode ser causada devido a presença de linhagens de leveduras geneticamente floculantes, as quais se agregam para formar flocos que sedimentam (Stratford \& Keenan, 1988) ou pela presença de bactérias contaminantes (Serra et al, 1979; Serra et al, 1980).

$\mathrm{Na}$ fermentação alcoólica industrial é freqüente a contaminação por bactérias lácticas principalmente do gênero Lactobacillus. Algumas dessas bactérias são capazes de provocar a floculação (Serra et al, 1979, Yokoya \& Oliva-Neto, 1991, Zaratini et al, 1993). Dentre as diversas espécies e linhagens, apenas algumas linhagens de L. fermentum mostraram ser eficientes provocadoras da floculação de leveduras (Yokoya \& Oliva-Neto, 1991).

Uma substância de natureza protéica responsável pela adesão da linhagem 737 de Lactobacillus fermentum ao epitélio gástrico de camundongo foi detectada por Conway \& Kjelleberg, $1989^{7}$, e foi citada por Yokoya \& Oliva-Neto, 1991, relacionando como possível causador da floculação de leveduras por bactérias, um fator semelhante a este de adesão.

${ }^{7}$ CONWAY, P. L. \& KJELLEBERG, S. Protein-mediated adhesion of Lactobacillus fermentum strain 737 to mouse stomach squamous epithelium. J. Gen. Microbial, v. $135,1175-86$ p. 1989. 
A floculação de leveduras causada por bactérias apresenta algumas características similares às leveduras floculantes, como susceptibilidade às altas temperaturas, proteinases e a pHs extremos; necessidade de íons metálicos e inibição por manose e excesso de íons. $O$ sítio suscetível a temperatura e proteinases está localizado na célula da bactéria e não da levedura, pois as células de levedura aquecidas com água em ebulição ou tratadas com proteinases são igualmente floculadas por bactérias (Yokoya e Oliva-Neto, 1991).

Mukay et al $1992^{8}$ citado por Frederick (1994) relataram atividade semelhante a lectina em Lactobacillus acidophilus através de ensaios de hemaglutinação e inibição de hemaglutinação, onde observaram tratar-se de um componente proteináceo firmemente associado à parede bacteriana.

Harty et al (1993) relataram pela primeira vez a capacidade de lactobacilos em agregar plaquetas humanas. Isolado da cavidade oral humana, L. fermentum $\mathrm{NCl}$ B6991 é capaz de agregar tais plaquetas. O componente responsável pela agregação parece envolver uma proteína termo-sensível da superficie do lactobacilo, contudo em eletroforese com gel poliacrilico-SDS, os autores citam que não foi possível indicar as diferenças entre linhagens agregantes de não agregantes.

MUKAY, T.; ARIHARA, K.; HIROSHI, I. Lectin-like activity of Lactobacillus acidophilus JCM 1026. FEMS Microbiol. Letters, v. 98, p. 71-74. 1992. 
Bromberg (1994) referiu-se a participação da porção protéica no fenômeno de floculação de leveduras, causado por L. fermentum 1405 isolado de dornas de fermentação alcoólica, após o tratamento com vários modificadores químicos. A autora não descartou a hipótese da possibilidade do fator de floculação ser constituído de uma glicoproteína, já que elevadas concentrações de periodato de sódio $(0,02 \mathrm{M})$ causaram inibição da floculação.

Santos (1991) observou que algumas linhagens de L. fermentum apresentam variação na força floculadora, podendo estar relacionada com o número de sítios de ligação. Também observou que a capacidade floculadora pode ser perdida durante o estoque e subcultivo da cultura, uma vez que $2 \%$ das colônias isoladas a partir de uma linhagem bacteriana fortemente floculante perderam a capacidade.

Frederick (1994) estudando aspectos genéticos, físiológicos e moleculares de L. fermentum envolvidos na floculação de levedura, definiu que as características morfológicas e bioquímicas das culturas da bactéria não apresentam diferenças significantes entre linhagens floculadoras e não floculadoras. Cita em seu trabalho que a floculação das leveduras ocorra devido à presença de uma capa protéica nas bactérias de natureza gelatinosa, fixando mecanicamente as células de levedura.

Também é conhecido que a floculação de leveduras causada por $L$. fermentum está ligada a presença da célula da bactéria, não sendo constituído, portanto, por metabólitos liberados no meio de cultivo durante o crescimento (Yokoya \& Oliva-Neto, 1991). Os autores citaram em seu trabalho que a floculação ocorre numa faixa mais ampla de $\mathrm{pH}$ (entre 2,0 e 12,0), se comparada com a floculação provocada por leveduras floculantes. As células 
desfloculadas a pH inferior a 2,5 podem sofrer o restabelecimento da floculação com o ajuste do $\mathrm{pH}$ a valores superiores a 2,5. Verificou-se que o problema da floculação de leveduras por contaminantes bacterianos tem sido intensificado pelo reciclo de células que consiste na reutilização do chamado "leite de levedura" (Yokoya, 1989).

Em seu estudo sobre o mecanismo de floculação da levedura, causada por L. fermentum, Bromberg, (1994) determinou uma relação entre a concentração de células da bactéria e da levedura a qual resulta na condição máxima de floculação, e sugeriu que esta floculação estaria envolvida com um mecanismo intercelular a nível da parede celular desses microrganismos. Ainda, segundo a autora, este processo deveria envolver componentes protéicos da superficie celular da bactéria, mais especificamente, grupos funcionais fenol e indol e, carboidratos da parede celular da levedura. 


\section{METODOLOGIA}

Os ensaios foram conduzidos junto ao laboratório de Açúcar e Álcool do Departamento de Ciência e Tecnologia Agroindustrial da Escola Superior de Agricultura "Luiz de Queiroz", Universidade de São Paulo, em Piracicaba São Paulo.

\subsection{Microrganismos}

Foram utilizadas culturas de $S$. cerevisiae (IZ 1904) e isolados de $L$. fermentum que fazem parte da coleção de microrganismos do Departamento de Ciência e Tecnologia Agroindustrial da Escola Superior de Agricultura "Luiz de Queiroz", Universidade de São Paulo.

\subsection{Meios de cultura}

Foram utilizados meios de cultura de preparações comerciais, na manutenção e reativação dos microrganismos e, para o crescimento do microrganismo durante os ensaios, foi desenvolvido meio de cultura à base de caldo de cana-de-açúcar, suplementado. 
3.2.1. Meios de manutenção e reativação dos microrganismos

- Litmus Milk ( Difco, 1984): manutenção sob congelamento, em freezer (cerca de $-18^{\circ} \mathrm{C}$ ) das culturas de L. fermentum.

- MRS (Lactobacilli Man, Rogosa e Sharpe) (Merck, 1992/93): reativação e manutenção das culturas de L. fermentum.

- YEPD-Agar: manutenção das culturas de $S$. cerevisiae sob refrigeração.

$$
\begin{aligned}
& \text { Extrato de levedura - 1\% } \\
& \text { Peptona - 1\% } \\
& \text { Dextrose - } 2 \% \\
& \text { Agar - } 1,5 \% \\
& \text { Água destilada }
\end{aligned}
$$

\subsubsection{Meios de cultura desenvolvidos para crescimento dos microrganismos}

Foram desenvolvidos meios de cultura à base de caldo de cana-deaçúcar suplementados para o cultivo dos microrganismos utilizados neste trabalho. 


\subsubsection{Matéria-prima e extração do caldo}

Após o corte, a cana-de-açúcar foi submetida a uma escovação através de uma escova metálica rotativa acionada por um motor elétrico, com o objetivo de se eliminar impurezas da superficie dos colmos, obtendo-se um caldo mais límpido. Seguindo a escovação, a extração do caldo foi efetuada em moenda de um terno, sob pressão do cilindro mestre de $1000 \mathrm{Kgf.cm}{ }^{-2}$, sem embebição. Foram utilizados os colmos inteiros, submetidos a três moagens consecutivas.

\subsubsection{Preparo do meio de cultura}

Após a extração, o caldo da cana foi submetido a filtração em algodão e em Celite 503, sob vácuo. O caldo clarificado foi submetido a esterilização em autoclave a $121{ }^{\circ} \mathrm{C}$ por 15 minutos e armazenado sob refrigeração em frascos tipo erlenmeyer de $1000 \mathrm{~mL}$, sendo utilizado no decorrer do experimento.

Para o preparo do meio de cultura, o caldo clarificado foi diluído em água destilada para $5,0 \pm 0,1^{\circ}$ Brix e suplementado com extrato de levedura $(1,0 \%)$ e peptona $(1,0 \%)$. Este meio de cultura líquido foi denominado de MCC e utilizado durante o experimento para o crescimento dos microrganismos. Como meio sólido foi utilizado o mesmo meio de cultura, acrescido de agar (1,5\%), sendo denominado de MCC-A. 


\subsection{Determinações físico-químicas}

3.3.1. Acidez total - determinada nas amostras de meio de cultura (MCC), nas culturas de L. fermentum e nas culturas mistas, segundo metodologia proposta pela Copersucar (1987), sendo o valor resultante convertido para ácido láctico, conforme Amerine (1974).

3.3.2. $\mathrm{pH}$ - determinada através da utilização de potenciômetro Digimed DMPH-2, no meio de cultura, durante o cultivo de L. fermentum e na cultura mista, segundo metodologia proposta pelo Instituto Adolpho Lutz (1985).

3.3.3. Brix refratométrico - determinado utilizando-se refratômetro digital Atago dbx-30 (Contec), em amostras do caldo de cana-de-açúcar, do caldo clarificado, do caldo diluído e na preparação dos meios de cultura (MCC e MCC-A), de acordo com Copersucar (1987).

3.3.4. Açúcares redutores totais (ART) - determinado através do método oxirredutimétrico de Somogyi \& Nelson, segundo Neish (1952).

\subsection{Determinações microbiológicas}

As análises microbiológicas consistiam em determinação da viabilidade celular e contagens de número de colônias, através de plaqueamentos. 


\subsubsection{Viabilidade celular}

Nos ensaios em culturas mistas de $S$. cerevisiae e L. fermentum foi determinada a viabilidade celular da levedura (Copersucar, 1987; Oliveira et al, 1996) utilizando-se como corante solução de azul de metileno e citrato de sódio. As células viáveis não se colorem devido a atividade fisiológica, enquanto que as inativas (mortas) apresentam-se coloridas de azul. A técnica consiste em misturar partes iguais da suspensão (amostra), previamente diluída, e de solução corante $(0,025 \mathrm{~g}$ de azul de metileno e $2,0 \mathrm{~g}$ de citrado de sódio, diluídas em $100 \mathrm{~mL}$ de água destilada).

As amostras foram analisadas em câmara de Neubauer através de microscópio óptico $\mathrm{BH}$ - Olympus e o resultado expresso em porcentagem (V\%) de células vivas, segundo a fórmula:

$$
\mathrm{V} \%=\frac{\text { Células vivas }}{\text { Total de células }} \times 100
$$

\subsubsection{Semeadura em placas}

Os plaqueamentos foram realizados utilizando-se a técnica alternativa denominada de "microplacas", e para viabilizar a utilização desta metodologia foram realizados ensaios comparativos com a técnica convencional "pour plate" ou semeadura em profundidade. 


\subsubsection{Semeadura em profundidade}

Nos plaqueamentos realizados pela técnica de "pour plate", também denominada semeadura em profundidade (Busta et al, 1984, Neder, 1992), foram utilizados meios MRS-Agar e MCC-Agar, seguindo metodologia convencional (Neder, 1992). Para as diluições foram utilizados tubos de ensaio contendo 9,0 mL de ambos os meios de cultura (Sharpe e Kilsby, 1971; Bryan-Jones, 1975).

Foram realizadas 36 placas por diluição, sendo as mesmas incubadas em estufa a $32^{\circ} \mathrm{C}$ por 24 a 48 horas. As contagens das colônias foram efetuadas em microscópio estereoscópio binocular VM-Micronal, sendo o resultado expresso em unidade formadora de colônias por mililitro (UFC/mL).

\subsubsection{Microplacas}

A técnica aqui denominada "microplacas" consistiu em uma adaptação do método de contagem de colonias denominada "Drop plate" (Thacther \& Clark, 1968; Sharpe \& Kilsby, 1971; Busta et al; 1984 ) ou "droplets" (Bryan-Jones, 1975). Alguns autores (Thacther \& Clark, 1968; Busta et al; 1984) indicam a metodologia para ser aplicada nas contagens de microrganismos mesofilicos aeróbios, analisados normalmente pela técnica de semeadura por profundidade.

Ao contrário do método de gotas, foram demarcados pequenos círculos em placas de Petri com tinta que formassem pequeno relevo e que servissem para conter um volume padronizado de $0,1 \mathrm{~mL}$. Cada círculo foi 
então denominado microplaca, onde seria feito a contagem de microrganismos após a incubação.

As demarcações foram feitas com tinta preta (pasta relevo vitral ref. 00860 - Acrilex) para contornos, testada para suportar esterilização em estufa e resistir a constantes lavagens, através de moldes, sendo desenhados nas placas 12 círculos de $1,0 \mathrm{~cm}$ de diâmetro, dispostos em 3 colunas e 4 linhas, onde os microrganismos foram inoculados, através de micropipetador (Transferpette $1.000 \mu \mathrm{L}$ - Brand; Figura 1). As diluições seriadas das amostras foram realizadas em tubos contendo meio de cultura homogeneizado e mantidas em banho a $38-40^{\circ} \mathrm{C}$, sendo semeadas no interior da câmara de fluxo laminar (Pachane 100) até a transferência de $0,1 \mathrm{~mL}$ do meio de cultura contendo a amostra para cada microplaca, totalizando 12 repetições por placa. A seguir as microplacas foram incubadas em estufa a $32^{\circ} \mathrm{C}$ por 24 a 48 horas e as colônias observadas através de microscópio estereoscópio binocular VMMicronal (x2), sendo a contagem final expressa em UFC/mL. 


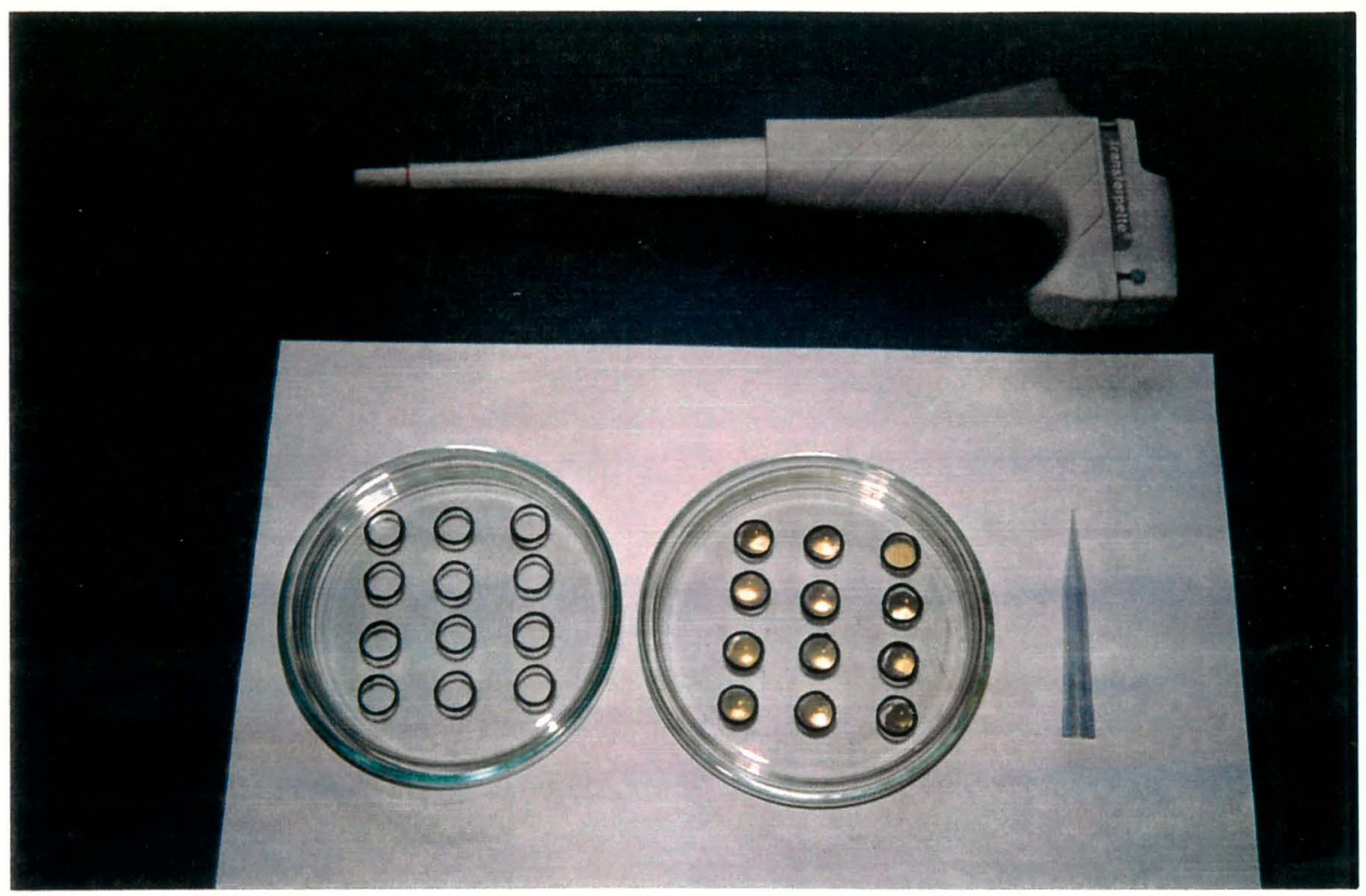

Figura 1. Micropipetador, ponteira e placas utilizadas nos plaqueamentos pela técnica de microplacas. 


\subsection{Cultivo de $S$. cerevisiae e L. fermentum}

Os microrganismos $S$. cerevisiae e L. fermentum foram cultivados separadamente, conforme metodologia descrita a seguir.

\subsubsection{Cultivo de L. fermentum}

As culturas estoque de $L$. fermentum foram mantidas congeladas em meio Litmus Milk. Para os ensaios foram reativadas após a transferência da cultura para $32^{\circ} \mathrm{C}$ por 24 a 48 horas ou até ocorrer a alteração da coloração do meio (reação ácida), indicando o desenvolvimento do microrganismo. Desta cultura foi transferida uma alíquota de $0,2 \mathrm{~mL}$ para tubo de ensaio contendo 5 $\mathrm{mL}$ de caldo MRS, constituindo-se a cultura de manutenção, a qual foi mantida sob refrigeração, com repique semanal, ou à temperatura ambiente e repiques mais freqüentes

Para o cultivo em MCC foi retirado $1 \mathrm{~mL}$ da cultura de manutenção e adicionados $9 \mathrm{~mL}$ de $\mathrm{MCC}$, sendo o tubo de ensaio incubado a $32^{\circ} \mathrm{C}$ por 24 horas. $\mathrm{O}$ volume de $10 \mathrm{~mL}$, após a incubação, foi transferido para erlenmeyer de $250 \mathrm{~mL}$ contendo $90 \mathrm{~mL}$ de meio MCC e incubado em estufa de cultura a $32^{\circ} \mathrm{C}$ por 24 horas (Figura 2).

O acompanhamento do crescimento do microrganismo foi efetuado através de leitura espectrofotométrica em comprimento de onda de $610 \mathrm{~nm}$ (espectrofotômetro digital Coleman SP-35D), tendo como referência o próprio meio de cultura. Foram realizados plaqueamentos nos tempos $0,24,48,72,96$ 
e 120 horas, a partir da amostra do cultivo, como também análises de $\mathrm{pH}$ e acidez total.

\subsubsection{Cultivo de $S$. cerevisiae}

As culturas de $S$. cerevisiae (IZ 1904) foram mantidas em meio de cultura YEPD-Agar (tubo inclinado) sob refrigeração. $\mathrm{Na}$ reativação foi retirada uma amostra equivalente a uma alça de transferência da cultura e transferida para frasco tipo erlenmeyer de $250 \mathrm{~mL}$, contendo $100 \mathrm{~mL}$ de meio de cultura MCC o frasco foi mantido a $32^{\circ} \mathrm{C}$ por 48 horas, em banho com agitação, tipo “ shaker-Dubnoff" MA 095 - Marconi.

\subsection{Composição das culturas mistas de $L$. fermentum e de S. cerevisiae}

Os ensaios utilizando culturas mistas de L. fermentum e de $S$. cerevisiae empregaram cultura mista ativa, cultura inativada por esterilização e inativada por agentes antibacterianos (Kamoran HJ 100 - Elanco e penicilina Pen-Ve-Oral 500.000 U.I. - Wyeth). 


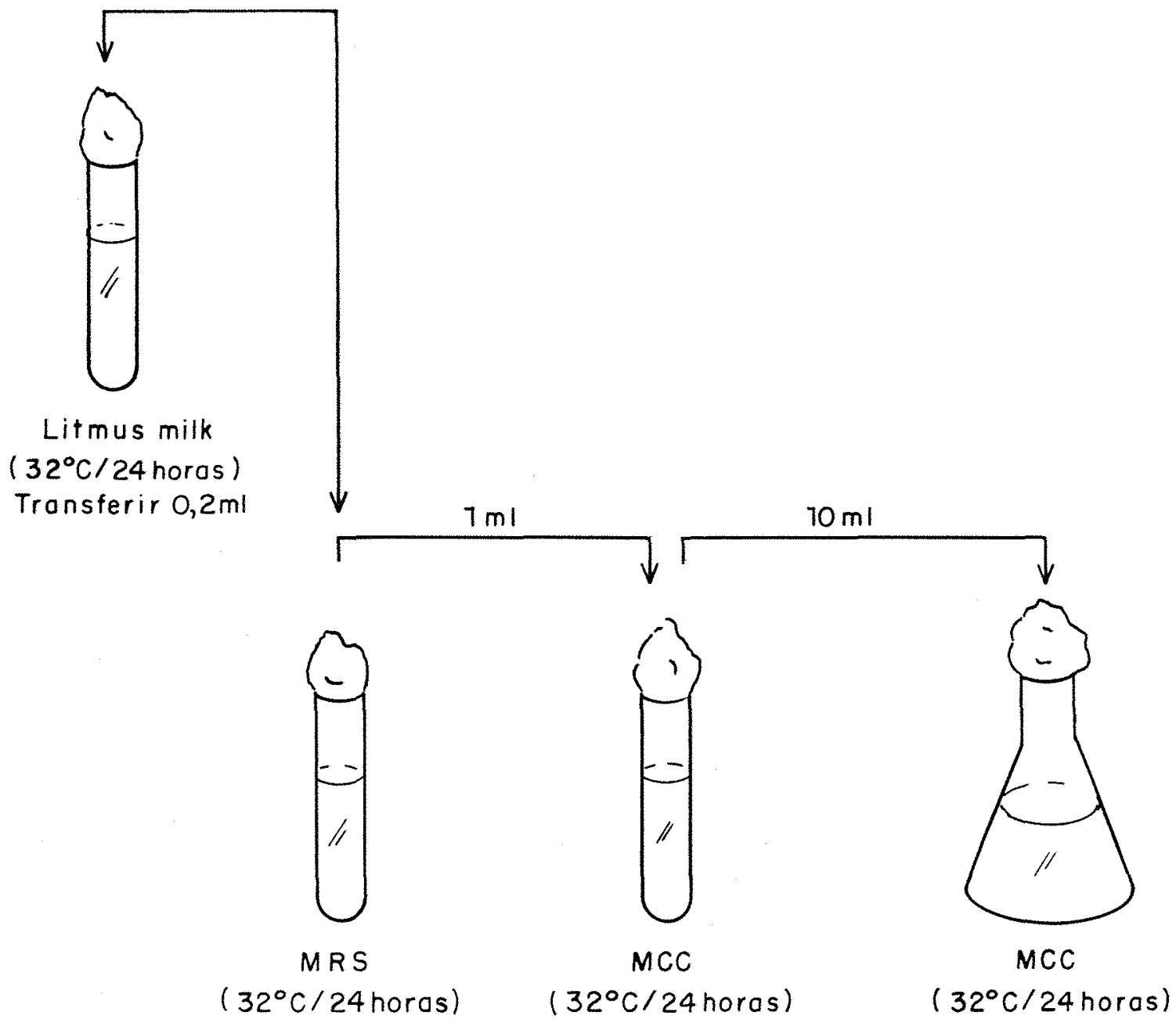

Figura 2. Técnica de cultivo de L. fermentum. 


\subsubsection{Cultura mista ativa}

A partir dos $100 \mathrm{~mL}$ de cultura de L. fermentum foram transferidas 2 alíquotas de $50 \mathrm{~mL}$ para 2 frascos erlenmeyer de $250 \mathrm{~mL}$ de capacidade, e adicionado em cada frasco, $50 \mathrm{~mL}$ de cultura de $S$. cerevisiae. Os frascos foram mantidos em estufa de cultura a $32^{\circ} \mathrm{C}$, como controle foi utilizado 100 $\mathrm{mL}$ da cultura de levedura preparado conforme item 3.5.2., sendo a viabilidade celular da cultura mista e do controle determinada em intervalos de 3 horas e os resultados expressos em porcentagem (\%) de células vivas.

\subsubsection{Cultura mista inativada}

O cultivo de L. fermentum foi submetido a processos de inativação através de calor ou da utilização de agentes antibacterianos.

\subsubsection{Cultura mista inativada por esterilização}

O cultivo de $L$. fermentum foi submetido a esterilização em autoclave a $120^{\circ} \mathrm{C}$ por 15 minutos e os ensaios sobre viabilidade celular seguiram a mesma metodologia descrita para as culturas mistas ativas. 


\subsubsection{Cultura mista inativada por agentes antibacterianos}

Para a inativação de L. fermentum por agentes antibacterianos, foram adicionados em $100 \mathrm{~mL}$, Kamoran HJ 100 (10 ppm; Elanco) ou penicilina Pen-Ve-Oral (125.000 U.I.; Wyeth), na cultura contendo a bactéria ativa. Após 24 horas de incubação em estufa de cultura a $32^{\circ} \mathrm{C}$, a viabilidade celular foi avaliada com base na metodologia aplicada para cultura mista ativa.

\subsection{Tratamento com enzimas e a capacidade floculante de \\ L. fermentum}

Foram utilizadas em ensaios preliminares, enzimas como pepsina, tripsina, papaína, bromelina e ficina, sendo verificada apenas a ação desfloculante ou não sobre os cultivos floculados, não levando em consideração as dosagens dessas enzimas.

\subsubsection{Enzimas utilizadas}

As enzimas de origem vegetal fornecidas pela Sigma, foram utilizadas na forma como são encontradas nas embalagens comerciais (papaína - 1,7 unidades/mg sólido, bromelina - 1,65 unidades/mg sólido e fícina 0,2 unidades/mg sólido) não havendo preocupação de estudar dosagens neste ensaio, em particular, sendo aplicado as seguintes doses: 
- Papaína: 1,15 unidades/ $10 \mathrm{~mL}$

- Bromelina: 25,41 unidades/10mL

- Ficina: 2,92 unidades/ $10 \mathrm{~mL}$

\subsubsection{Determinação do efeito do tratamento enzimático sobre a capacidade floculante de $L$. fermentum em cultura mista ativa}

Utilizando-se a metodologia descrita para cultura mista ativa, as culturas de L. fermentum e $S$. cerevisiae foram misturadas e homogeneizadas através de agitação em "Shaker-Dubnoff" MA 095, por 30 minutos a $32^{\circ} \mathrm{C}$, sendo observado a formação de flocos. Para os testes de floculação, foram retirados $1 \mathrm{~mL}$ do material floculado, os quais foram transferidos para tubos cônicos graduados de centrífuga sendo adicionados $9,0 \mathrm{~mL}$ de água destilada, tanto nos tubos contendo o controle como nos tubos contendo as enzimas. Após centrifugação a $1000 \mathrm{~g}$ por 10 minutos em centrífuga Excelsa Baby I, o sobrenadante foi descartado e o material ressuspenso em $9,0 \mathrm{ml}$ de água destilada, sendo a seguir acrescentadas as enzimas. $O$ material foi homogeneizado por agitação durante 10 segundos, em agitador de tubos Phoenix AP 56, sendo colocado em repouso por 10 minutos; a seguir o sobrenadante foi retirado e efetuadas leituras a $600 \mathrm{~nm}$, em espectrofotômetro digital Coleman SP35-D, (Santos, 1991).

No acompanhamento do efeito do tratamento enzimático sobre a capacidade floculadora de L. fermentum, foram realizados ensaios fotográficos dos tratamento, para melhor se avaliar a atuação das enzimas utilizadas. $\mathrm{O}$ 
material foi fotografado utilizando-se microscópio óptico - Leika Micro Star IV, com máquina fotográfica acoplada (Yashica mod. 108 multiprogram). 


\section{RESULTADOS E DISCUSSÃO}

A ocorrência de floculação decorrente de interação microbiana em fermentação industrial de produção de álcool tem sido sempre acompanhada de sensível queda da porcentagem de células viáveis de levedura. Os resultados a seguir apresentados visam esclarecer alguns dos contravertidos pontos da interação entre microrganismos e o meio em culturas mistas.

Inicialmente, foi procurada uma metodologia que permitisse a avaliação de contagem de colônias e de meio de cultura adequados aos propósitos que são apresentados a seguir.

\subsection{Metodologias alternativas de contagem e cultura}

Os resultados envolvendo a avaliação da metodologia de contagem e meio de cultura alternativos são apresentados a seguir:

\subsubsection{Metodologia de contagem por microplacas}

Os resultados avaliando as metodologias de contagens das colônias de L. fermentum e de S. cerevisiae são apresentados na Tabela 1. 
Tabela 1 - Resultados das contagens de colônias de L. fermentum e S. cerevisiae, comparando as técnicas de semeadura em profundidade e microplacas.

\begin{tabular}{llll}
\hline Microrganismo & Técnica & UFC/mL & \\
& &
\end{tabular}

\begin{tabular}{|c|c|c|c|}
\hline \multirow[t]{2}{*}{ L. fermentum } & Microplacas $^{(b)}$ & $1,35 \times 10^{9}$ & $\pm 0,35 \times 10^{9}$ \\
\hline & Profundidade $^{(b)}$ & $1,30 \times 10^{9}$ & $\pm 0,32 \times 10^{9}$ \\
\hline \multirow[t]{2}{*}{ S. cerevisiae } & Microplacas $^{(b)}$ & $2,60 \times 10^{6}$ & $\pm 1,16 \times 10^{6}$ \\
\hline & Profundidade $^{(b)}$ & $2,57 \times 10^{6}$ & $\pm 1,19 \times 10^{6}$ \\
\hline
\end{tabular}

A técnica alternativa de contagem total de microrganismos foi adaptada de metodologia indicada para grande quantidade de leituras em placas, sendo considerada mais rápida e econômica do que o método de semeadura em profundidade (Bryan-Jones, 1975).

Assim, a utilização desta técnica alternativa, denominada microplacas, reduz sensívelmente o consumo de componentes e do meio de cultura em si, além de vidraria e espaço necessários para a incubação. A técnica possibilita que se façam muitas contagens repetidas, sendo indicada para qualquer laboratório, desde que os meios e condições sejam convenientemente estudadas e adaptadas aos microrganismos que se deseja pesquisar. 


\subsubsection{Meio alternativo de cultura}

Os ensaios comparativos do crescimento de L. fermentum nos meios MRS-Agar e MCC-Agar, através de técnica de semeadura em profundidade e microplacas são apresentados na Tabela 2.

Tabela 2. Crescimento de L. fermentum nos meios MRS-A e MCC-A, comparando a metodologia de semeadura em profundidade e microplacas.

\begin{tabular}{cccc}
\hline Meio de cultura & Técnica & ${\mathbf{U F C} / \mathbf{m L}^{(\mathbf{a})}}$ & $\sigma$ \\
\hline MRS-A & profundidade $^{(\mathrm{b})}$ & $1,00 \times 10^{9}$ & $\pm 0,25 \times 10^{9}$ \\
MCC-A & & $1,00 \times 10^{9}$ & $\pm 0,55 \times 10^{9}$ \\
MRS-A & microplacas $^{(\mathrm{b})}$ & $3,11 \times 10^{9}$ & $\pm 0,70 \times 10^{9}$ \\
MCC-A & & $3,19 \times 10^{9}$ & $\pm 0,52 \times 10^{9}$
\end{tabular}

${ }^{(2)} \mathrm{UFC}$ : Unidade formadora de colônias

${ }^{(b)}$ Média de 5 ensaios (36 leituras cada)

O meio de cultura MCC-A foi desenvolvido em substituição ao MRSA, por ser simples, acessível e muito econômico. A suplementação do caldo de cana com peptona e extrato de levedura estimulou o aumento da população de bactérias, uma vez que em meio com caldo de cana desidratado a $4 \%$ não ocorreu crescimento de L. fermentum em cultivo puro (Oliva-Neto, 1995). 
Ainda, segundo o autor, os aminoácidos são os principais componentes presentes no extrato de levedura que estimulam o crescimento das bactérias lácticas durante a fermentação alcoólica.

Em Seminário Agroindustrial Luiz de Queiroz, Horii (1983) apresentou um trabalho sobre isolamento de bactérias lácticas de fermentação alcoólica em meio de caldo de cana-de-açúcar clarificado, diluído a $8^{\circ}$ Brix e suplementado com extrato de leveduras e actidiona. A técnica vinha sendo desenvolvida para detecção e contagem de bactérias do caldo.

\subsection{Cultivo de $L$. fermentum em meio de cultura MCC}

Acompanhando o cultivo de L. fermentum em meio MCC através de leituras turbidimétricas, foi observada maior alteração de turbidez nas primeiras 12 horas (Tabela 3), o que representou maior crescimento do microrganismo neste período. Os resultados dos plaqueamentos apresentaram aumento da população bacteriana no mesmo período, porém a concentração populacional manteve-se, praticamente até a leitura após 24 horas (Tabela 4). 
Tabela 3. Avaliação do desenvolvimento de L. fermentum em MCC, medido através de análise turbidimétrica ${ }^{(a)}$.

\begin{tabular}{ccc}
\hline Tempo (h) & Transmitância (\%) & $\sigma$ \\
\hline $0: 00$ & 82,2 & $\pm 1,25$ \\
$3: 00$ & 79,4 & $\pm 0,69$ \\
$6: 00$ & 75,8 & $\pm 1,90$ \\
$9: 00$ & 43,6 & $\pm 2,41$ \\
$12: 00$ & 13,9 & $\pm 1,10$ \\
$24: 00$ & 7,9 & $\pm 0,13$ \\
$27: 00$ & 7,9 & $\pm 0,15$ \\
$30: 00$ & 7,8 & $\pm 0,17$
\end{tabular}

(3) Média de 7 ensaios

Tabela 4. Desenvolvimento de L. fermentum em meio de cultura $\mathrm{MCC}-\mathrm{A}^{(\mathrm{a})}$.

\begin{tabular}{ccc}
\hline Tempo (h) & UFC/mL & $\sigma$ \\
\hline $0: 00$ & $5,84 \times 10^{6}$ & $\pm 1,53 \times 10^{6}$ \\
$6: 00$ & $7,52 \times 10^{7}$ & $\pm 1,80 \times 10^{7}$ \\
$12: 00$ & $5,27 \times 10^{8}$ & $\pm 1,57 \times 10^{8}$ \\
$24: 00$ & $4,24 \times 10^{8}$ & $\pm 1,52 \times 10^{8}$ \\
\hline
\end{tabular}

(3) Média de 7 ensaios (36 leituras cada)

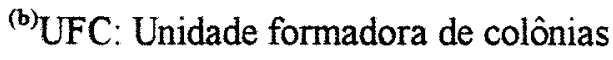


Foi realizado o acompanhamento da acidez e do $\mathrm{pH}$ do meio durante o crescimento das culturas de L. fermentum em MCC após diferentes tempos e os resultados médios de 3 ensaios estão apresentados na Tabela 5. Observouse um crescimento da população do microrganismo até 24 horas, seguido de queda, que pode estar relacionada à acidez e $\mathrm{pH}$ do meio ou ainda a possíveis deficiências nutricionais de cultivo. Aliás, o pH do caldo coincide com os resultados obtidos por Pitta \& Horii (1986) quando o caldo foi mantido em condição ambiente e o pH, a acidez e a concentração de colônias avaliados ao longo de 144 horas. $\mathrm{O} \mathrm{pH}$ em torno de 3,5 é restritivo ao crescimento bacteriano da maioria das espécies ocorrentes, como citado em Tilbury (1975).

Tabela 5. Acidez total, pH e população de L. fermentum em diferentes tempos, em meio $\mathrm{MCC}^{(\mathrm{a})}$.

\begin{tabular}{cccc}
\hline Tempo (h) & Acidez láctica (g/L) & pH & UFC/mL \\
\hline $0: 00$ & 2,85 & 5,86 & $4,20 \times 10^{6}$ \\
$24: 00$ & 10,45 & 3,52 & $9,33 \times 10^{8}$ \\
$48: 00$ & 11,32 & 3,45 & $2,50 \times 10^{7}$ \\
$72: 00$ & 11,58 & 3,45 & $1,87 \times 10^{5}$ \\
$96: 00$ & 11,89 & 3,44 & $1,95 \times 10^{4}$ \\
$120: 00$ & 12,01 & 3,44 & $2,96 \times 10^{3}$ \\
& & & \\
$\begin{array}{l}\text { (a) Média de 3 ensaios } \\
\text { (b) UFC: Unidade formadora de colônias }\end{array}$ & & \\
\hline
\end{tabular}




\subsection{Algumas características dos cultivos de $L$. fermentum} e $S$. cerevisiae

Os cultivos de L. fermentum e $S$. cerevisiae foram analisados em relação a pH, acidez láctica, ART viabilidade e unidades formadoras de colônias por mililitro (Tabela 6).

Tabela 6. Resultados dos cultivos de L. fermentum e S. cerevisiae, antes da composição das partes que resultaram na cultura mista ${ }^{(a)}$.

\begin{tabular}{ccccccc}
\hline Cultivo & $\begin{array}{c}\text { Tempo } \\
\text { (h) }\end{array}$ & $\mathbf{p H}$ & $\begin{array}{c}\text { Acidez } \\
\text { láctica (g/L) }\end{array}$ & $\begin{array}{c}\mathbf{A R T}^{(\mathbf{b})} \\
(\mathbf{g} / \mathbf{L})\end{array}$ & $\mathbf{V ( \% )}$ & \\
\hline L.fermentum & $24: 00$ & 3,57 & 10,48 & 2,25 & - & $4,36 \times 10^{8}$ \\
S.cerevisiae & $48: 00$ & 4,24 & 6,70 & 2,74 & 96,95 & $5,21 \times 10^{7}$ \\
\hline
\end{tabular}

(a) Média de 3 ensaios

${ }^{(b)}$ ART: Açúcares redutores totais

${ }^{(c)} \mathrm{V}(\%)$ : Viabilidade celular expresso em porcentagem

${ }^{(d)}$ UFC: Unidade formadora de colônias

\subsection{Ensaios utilizando cultura mista}

As culturas mistas foram divididas em cultura mista ativa e cultura mista inativada por esterilização ou por antimicrobianos. Numa primeira etapa 
foram comparados cultura mista ativa e inativada por esterilização. A seguir, cultura mista ativa e inativada por esterilização e por antibacterianos.

\subsubsection{Cultura mista ativa}

Observa-se através dos resultados apresentados na Tabela 7 que a mistura de volumes iguais de cultivos isolados de $L$. fermentum e $S$. cerevisiae provocaram uma rápida e intensa queda de viabilidade da levedura, de cerca de $97 \%$ em relação ao controle, após 12 horas. Através do plaqueamento observou-se que a cultura controle não apresentou alteração quanto ao número de UFC/mL (Tabela 8) enquanto que a cultura mista apresentou praticamente só formação de colônias bacterianas devido a redução da viabilidade das células de levedura, como observado na análise de viabilidade celular. 
Tabela 7. Viabilidade celular da levedura S. cerevisiae em presença de L. fermentum (cultura mista ativa) ${ }^{(a)}$.

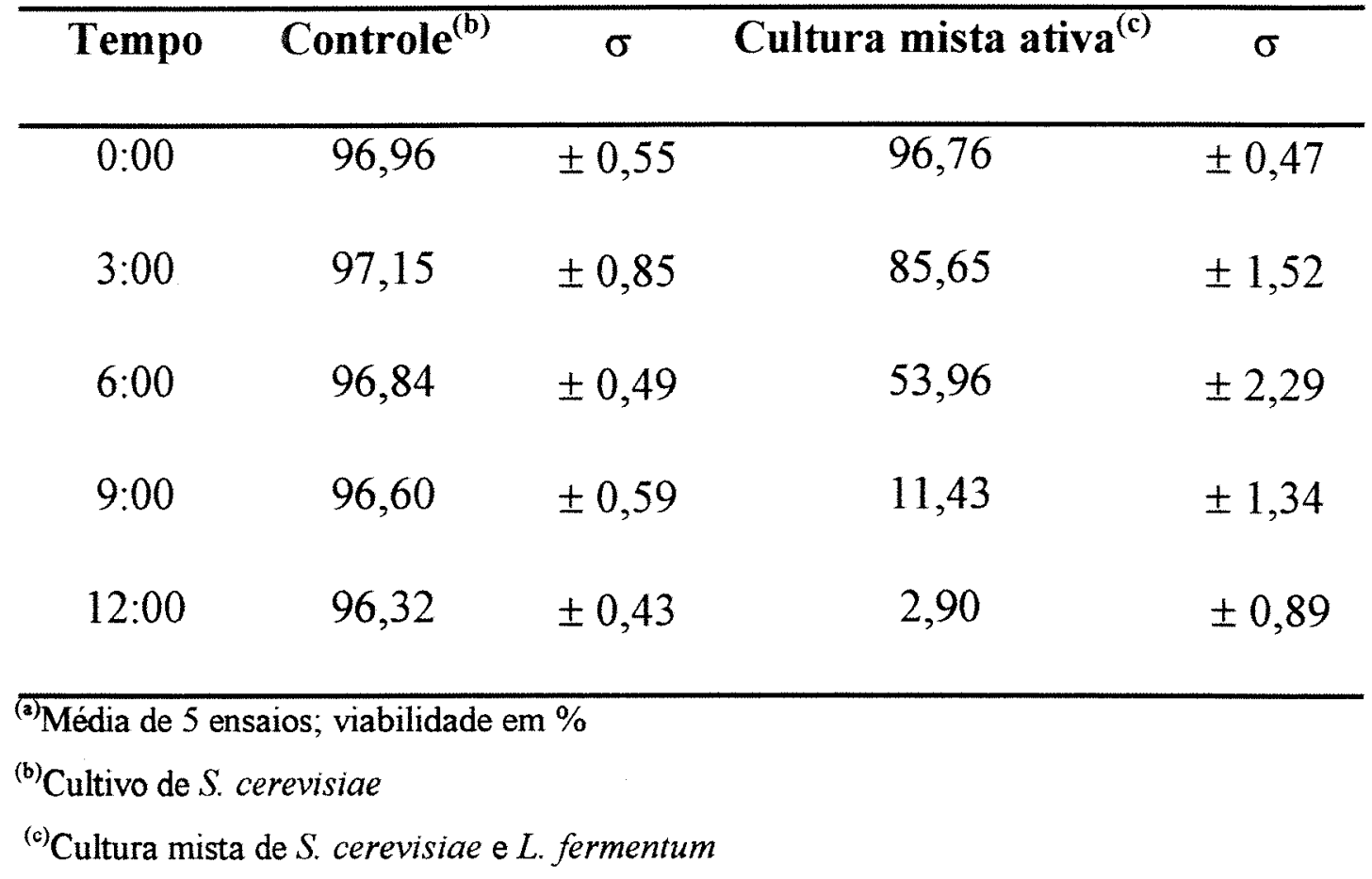

Tabela 8. Avaliação das populações inicial e final dos microrganismos nos ensaios com cultura mista ativa ${ }^{(a)}$.

\begin{tabular}{cccc}
\hline Tempo (h) & Amostra & UFC/mL & $\sigma$ \\
\hline $0: 00$ & L. fermentum & $2,96 \times 10^{8}$ & $\pm 1,45 \times 10^{8}$ \\
& Controle $^{(\mathrm{c})}$ & $6,67 \times 10^{7}$ & $\pm 2,04 \times 10^{7}$ \\
\multirow{2}{*}{$12: 00$} & Cultura mista & & \\
& ativa $^{(\mathrm{d})}$ & $1,69 \times 10^{8}$ & $\pm 1,33 \times 10^{8}$ \\
& Controle $^{(\mathrm{c})}$ & $6,61 \times 10^{7}$ & $\pm 2,09 \times 10^{7}$ \\
\hline
\end{tabular}

\footnotetext{
${ }^{(a)}$ Média de 5 ensaios (36 leituras cada)

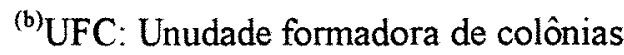

${ }^{(\mathrm{c})}$ Cultivo de $S$. cerevisiae

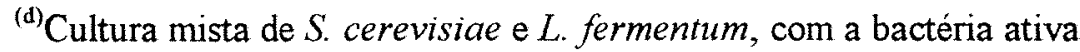




\subsubsection{Cultura mista inativada por esterilização}

Analisando os ensaios de viabilidade de leveduras com adição de culturas de L. fermentum inativada por esterilização, pode-se observar redução média de 55\% nas primeiras 12 horas em relação ao controle (Tabela 9). Após 30 horas a queda na viabilidade da levedura chegou a cerca de $98 \%$. A Tabela 10 apresenta a contagem de colônias obtidas após 30 horas, evidenciando uma redução de aproximadamente $100 \%$ do total destas colônias.

Os resultados dos plaqueamentos apontam para a crescente redução do número de colônias de leveduras remanescentes no meio contendo cultura inativada de L. fermentum. Anteriormente, Yokoya e Oliva-Neto (1991) citaram em seu trabalho a inativação da capacidade floculadora pelo tratamento térmico a $55^{\circ} \mathrm{C}$. Entretanto, foi possível detectar que a queda de viabilidade de levedura pode estar mais influenciada pelo efeito de um ou mais metabólitos do que pela capacidade floculadora do microrganismo. Aliás, em ensaio preliminar, observou-se que placas contendo culturas mistas apresentavam, após 3 a 4 dias, colônias com alteração de cor que se verificou serem constituídas por células mortas, em tempos muito inferiores ao esperado, já que as colônias se encontravam suficientemente esparssas nas placas. 
Tabela 9. Viabilidade celular da levedura S. cerevisiae na presença de L. fermentum (cultura mista inativada por esterilização) ${ }^{(a)}$.

\begin{tabular}{ccccc}
\hline Tempo & Controle $^{(\mathrm{b})}$ & $\sigma$ & $\begin{array}{c}\text { Cultura mista } \\
\text { inativada }^{(\mathrm{c})}\end{array}$ & $\sigma$ \\
\hline $0: 00$ & 97,32 & $\pm 0,55$ & 96,98 & $\pm 0,50$ \\
$3: 00$ & 97,23 & $\pm 0,79$ & 92,69 & $\pm 4,15$ \\
$6: 00$ & 97,13 & $\pm 0,70$ & 79,68 & $\pm 2,96$ \\
$9: 00$ & 96,90 & $\pm 0,38$ & 62,32 & $\pm 2,14$ \\
$12: 00$ & 96,37 & $\pm 0,66$ & 43,83 & $\pm 4,93$ \\
$24: 00$ & 95,83 & $\pm 0,29$ & 12,78 & $\pm 1,73$ \\
$27: 00$ & 95,84 & $\pm 0,34$ & 6,28 & $\pm 0,97$ \\
$30: 00$ & 95,57 & $\pm 0,39$ & 2,00 & $\pm 0,87$ \\
\hline
\end{tabular}

(a) Média de 5 ensaios; viabilidade em \%

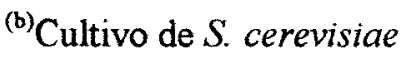

${ }^{(c)}$ Cultura mista de $S$. cerevisiae e $L$. fermentum, com a bactéria inativada por esterilização 
Tabela 10. Avaliação das populações inicial e final dos microrganismos nos ensaios com cultura mista inativada por esterilização ${ }^{(a)}$.

\begin{tabular}{cccc}
\hline Tempo & Amostra & ${\text { UFC } / \mathbf{m L}^{(\mathbf{b})}}$ & $\sigma$ \\
\hline $0: 00$ & L. fermentum & 0 & 0 \\
& Controle $^{(\mathrm{c})}$ & $7,50 \times 10^{7}$ & $\pm 2,49 \times 10^{7}$ \\
\multirow{2}{*}{$30: 00$} & Cultura mista $^{(\mathrm{d})}$ & & \\
& inativada $^{(\mathrm{d})}$ & $1,17 \times 10^{5}$ & $\pm 0,39 \times 10^{5}$ \\
& Controle $^{(\mathrm{c})}$ & $7,08 \times 10^{7}$ & $\pm 2,37 \times 10^{7}$ \\
\hline
\end{tabular}

${ }^{(3)}$ Média de 5 ensaios (36 leituras cada)

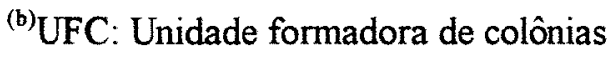

${ }^{(c)}$ Cultivo de $S$. cerevisiae

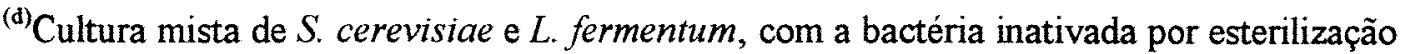

Comparando as médias dos tratamentos (Figura 3), foi observado que apesar de diferenças quanto a atuação sobre a célula da levedura, a presença de L. fermentum e/ou de seus produtos metabólicos levam a diminuição na viabilidade celular da levedura, quando comparadas ao controle. Segundo Oliva-Neto (1995), nutrientes nitrogenados liberados pela autólise das próprias leveduras, durante a fermentação podem estimular o crescimento populacional da contaminação por bactérias na fermentação alcoólica e, estarem associados a permanência destes contaminantes no processo.

Avaliando os resultados do presente trabalho, torna-se importante ressaltar que nos processos fermentativos é fundamental evitar severas contaminações por microrganismos desde a matéria-prima e nas etapas iniciais do processamento, pois, os seus produtos metabólicos tóxicos podem provocar 
quedas de viabilidade e consequentemente, redução da massa de células principalmente em períodos pós-fermentação. Fenômenos desse tipo podem ser observados pelos resultados encontrados por Oliva-Neto (1995).

\subsubsection{Comparação entre cultura mista inativada por esterilização e por antibacterianos}

O procedimento denominado cultura mista inativada por esterilização foi repetido para se verificar a influência do meio no qual se utilizou os agentes antibacterianos. A razão deste tratamento foi de se comparar a hipótese do surgimento de possíveis compostos, alteração causada no meio pelo tratamento térmico que pudessem ser considerados responsáveis pela redução da viabilidade

Os agentes antibacterianos utilizados foram Kamoran HJ 100 (10 ppm) e penicilina V potássica (125.000 U.I.). Segundo Oliveira et al (1996), antibacterianos como Kamoran $\mathrm{HJ}$, a virginiamicina e a penicilina são os mais utilizados na indústria de álcool. 


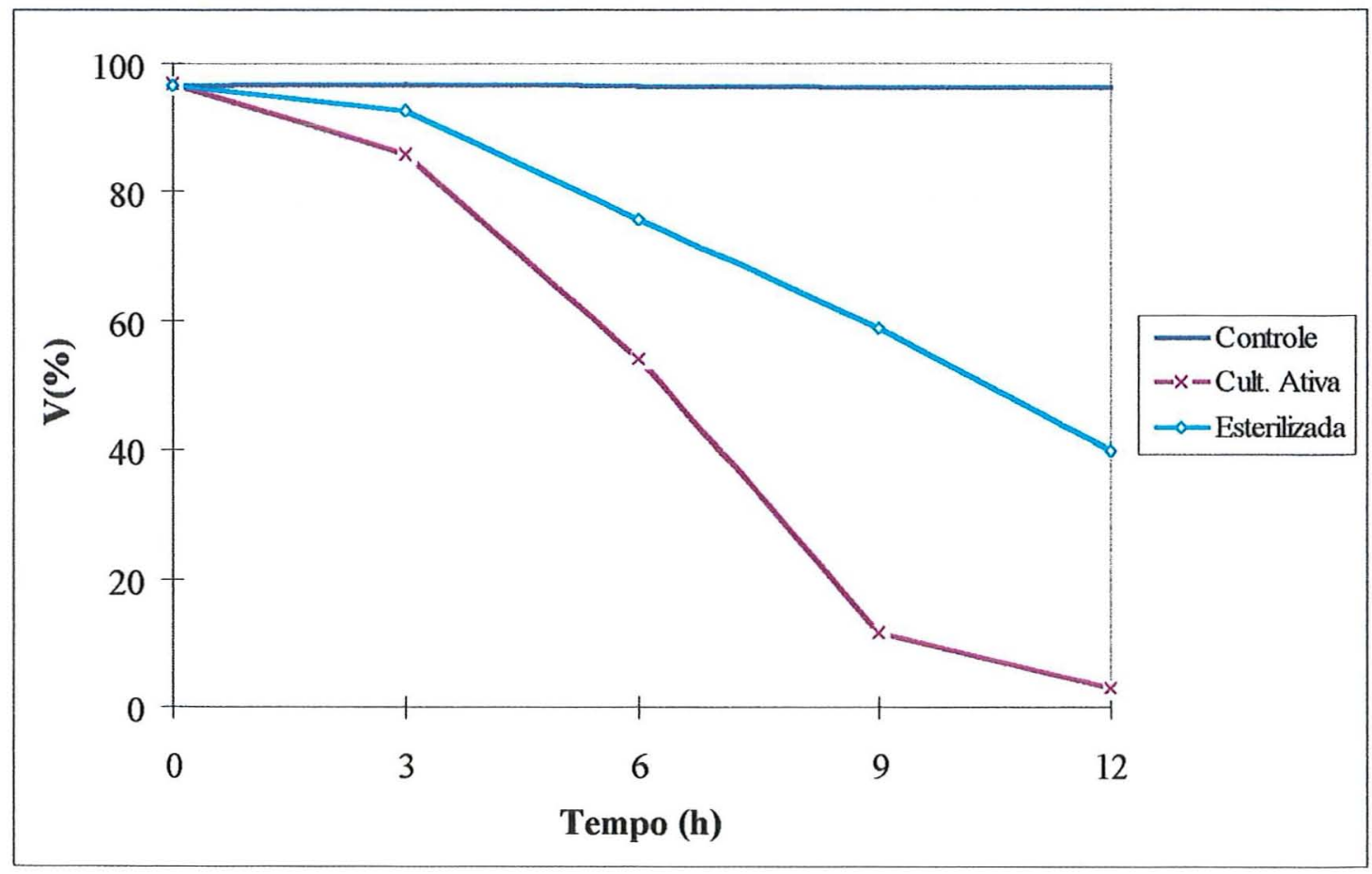

Figura 3. Viabilidade celular da levedura S. cerevisiae nos tratamentos controle, cultura mista ativa e inativada por esterilização. 


\subsubsection{Cultura mista inativada por Kamoran $\mathrm{HJ}$}

Com relação ao Kamoran $\mathrm{HJ}$, a dosagem recomendada para uso industrial é de 1 a 3 ppm, mas existe citação da aplicação de até 6 ppm, onde observou-se reduções de $99,99 \%$ nas culturas de L. fermentum (Oliveira et al 1996).

A dosagem aplicada de 10 ppm impediu o crescimento de colônias de L. fermentum nas placas analisadas. Foram realizados plaqueamentos nos tempos 6,12 e 24 horas após aplicação. $O$ intervalo de tempo utilizado para compor a cultura mista neste ensaio foi de 24 horas após a dosagem do antibacteriano. Com relação a levedura, as células não apresentaram alterações quanto a viabilidade, quando comparadas ao controle.

No tratamento Kamoran HJ (Tabela 11), a cultura mista apresentou queda de viabilidade da levedura $S$. cerevisiae em cerca de $63 \%$ em 12 horas, chegando a $92 \%$ em 24 horas.

\subsubsection{Cultura mista inativada por penicilina $\mathrm{V}$ potássica}

A penicilina, também é muito utilizada durante o processo de fabricação de álcool e sua atuação leva a uma inibição da biossíntese de constituintes essenciais da membrana, interferindo no transporte ativo através da mesma (Eguchi, 1989).

Para a penicilina foi seguido o mesmo procedimento do Kamoran $\mathrm{HJ}$, aplicando-se dosagens de 1.250 U.I./mL. O plaqueamento do cultivo de $L$. fermentum, onde foram dosadas a penicilina, não apresentou crescimento da bactéria, quando avaliado nos mesmos intervalos descritos para Kamoran HJ. 
Igualmente, a utilização da penicilina não causou alterações na cultura de levedura, quando comparada ao controle.

Foi observado queda de viabilidade das células de $S$. cerevisiae em cerca de $60 \%$ nas primeiras 12 horas, passando para $92 \%$ em 24 horas cujos dados constam da Tabela 12.

Tabela 11. Viabilidade celular da levedura S. cerevisiae na presença de L. fermentum, inativada por Kamoran $\mathrm{HJ}^{(\mathrm{a})}$.

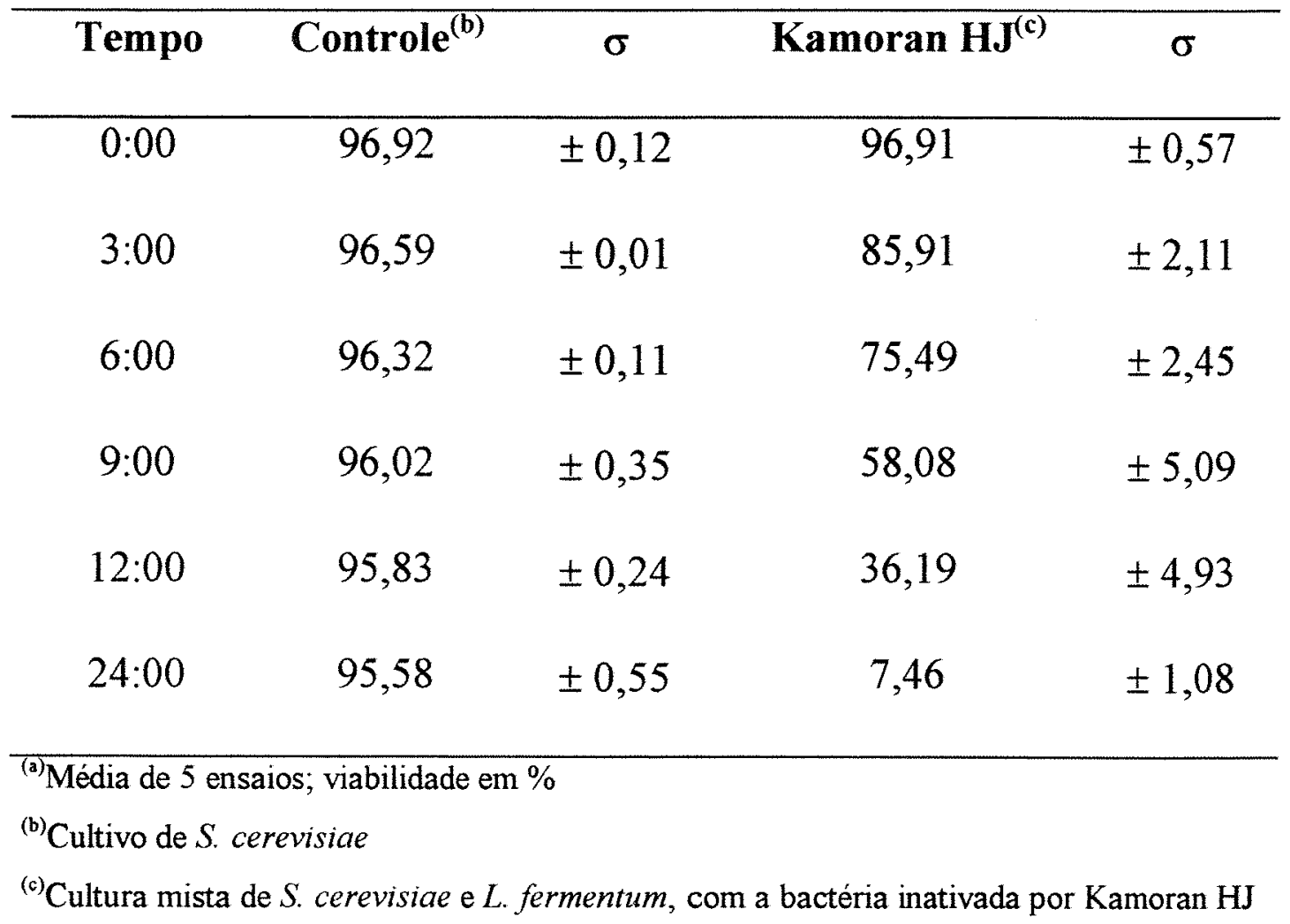


Tabela 12. Viabilidade celular da levedura $S$. cerevisiae na presença de L. fermentum, inativada por penicilina $\mathrm{V}$ potássica ${ }^{(\mathrm{a})}$.

\begin{tabular}{ccccc}
\hline Tempo & Controle $^{(\mathrm{b})}$ & $\sigma$ & $\begin{array}{c}\text { Penicilina V } \\
\text { potássica }^{(\mathbf{c})}\end{array}$ & $\sigma$ \\
\hline $0: 00$ & 96,47 & $\pm 0,20$ & 96,93 & $\pm 0,61$ \\
$3: 00$ & 96,40 & $\pm 0,13$ & 88,30 & $\pm 2,36$ \\
$6: 00$ & 96,29 & $\pm 0,13$ & 76,82 & $\pm 3,49$ \\
$9: 00$ & 96,24 & $\pm 0,20$ & 60,42 & $\pm 1,36$ \\
$12: 00$ & 96,10 & $\pm 0,05$ & 38,53 & $\pm 3,96$ \\
$24: 00$ & 96,02 & $\pm 0,863$ & 7,85 & $\pm 1,545$ \\
\hline
\end{tabular}

${ }^{(a)}$ Média de 5 ensaios; viabilidade em \%

${ }^{(b)}$ Cultivo de $S$. cerevisiae

${ }^{(c)}$ Cultura mista de $S$. cerevisiae e $L$. fermentum, com a bactéria inativada por penicilina $\mathrm{V}$ potássica

\subsubsection{Cultura mista ativa e inativada por esterilização}

Os resultados sobre a viabilidade celular da levedura $S$. cerevisiae obtidos nos tratamentos inativada por esterilização e cultura ativa (Tabela 13) apresentaram comportamentos semelhantes aos já descritos nos itens $4.4 .1 \mathrm{e}$ 4.4.2., com reduções de cerca de $49 \%$ e $95 \%$ da viabilidade, respectivamente, nas primeiras 12 horas. 
Tabela 13. Viabilidade celular da levedura S. cerevisiae em cultura mista ativa e inativada por esterilização ${ }^{(a)}$.

\begin{tabular}{ccccccc}
\hline Tempo & Controle $^{(\mathbf{a})}$ & $\sigma$ & Esterilizada $^{(\mathbf{b})}$ & $\sigma$ & Ativa $^{(\mathbf{c})}$ & $\sigma$ \\
\hline $0: 00$ & 96,95 & $\pm 0,38$ & 97,07 & $\pm 0,59$ & 97,00 & $\pm 0,38$ \\
$3: 00$ & 96,92 & $\pm 0,39$ & 94,28 & $\pm 2,95$ & 82,13 & $\pm 3,02$ \\
$6: 00$ & 96,74 & $\pm 0,44$ & 81,67 & $\pm 1,20$ & 54,58 & $\pm 5,71$ \\
$9: 00$ & 96,75 & $\pm 0,42$ & 71,61 & $\pm 4,91$ & 29,09 & $\pm 5,99$ \\
$12: 00$ & 96,51 & $\pm 0,49$ & 49,60 & $\pm 3,98$ & 4,85 & $\pm 1,75$ \\
$24: 00$ & 95,54 & $\pm 1,13$ & 18,84 & $\pm 1,15$ & $<1,00$ & - \\
\hline
\end{tabular}

(a) Média de 5 ensaios; viabilidade em \%

${ }^{(b)}$ Cultivo de $S$. cerevisiae

${ }^{(c)}$ Cultura mista de $S$. cerevisiae e $L$. fermentum, com a bactéria inativada por esterilização

${ }^{\text {(d) }}$ Cultura mista de $S$. cerevisiae e $L$. fermentum, com a bactéria ativa

A Figura 4 ilustra o comportamento das culturas de $S$. cerevisiae nos 5 tratamentos realizados. Enquanto a viabilidade celular do controle não apresenta alterações, todos os tratamentos apresentam tendências similares que vão se acentuando da inativada por esterilização, para os agentes antibacterianos (Kamoran $\mathrm{HJ}$ e penicilina $\mathrm{V}$ potássica), que se comportam da mesma forma e a ativa que possue o mais acentuado perfil de redução da viabilidade celular. A população ativa em termos de $\log \mathrm{UFC} / \mathrm{mL}$ dos tratamentos anteriormente referidos são apresentados na Figura 5. 
Quanto a floculação, esta só foi observada nos tratamentos com culturas mistas ativas, não ocorrendo nos tratamentos com culturas mistas inativadas (esterilização e antibacterianos). Yokoya e Oliva-Neto (1991) já haviam observado este efeito e concluiram que o fator responsável pela floculação estava ligado a presença da célula da bactéria L. fermentum, não sendo constituído por metabólitos liberados no meio de cultura durante o seu crescimento.

Com relação aos resultados obtidos com as análises de acidez ( $\mathrm{g}$ ácido láctico/L) e $\mathrm{pH}$ (Tabela 14), os tratamentos inativada por esterilização, Kamoran $\mathrm{HJ}$ e penicilina $\mathrm{V}$ potássica também apresentaram resultados muito próximos, porém, com valores mais altos para tratamento inativada por esterilização.

A observação de que o tratamento de inativação pelo calor levou a obtenção de resultados que contém a mesma tendência, porém, de maneira atenuada nos tempos estudados sugere que os componentes ou princípios ativos podem ter sido parcialmente reduzidos em termos de concentração ou modificada de tal modo que sua ação ainda permanece, porém, menos ativa.

Muitos autores (Maiorella et al 1983; Yokoya, 1991; Makanjiola, 1992; Oliva-Neto, 1995) discutem a ação inibitória dos ácidos orgânicos sobre os processos de fermentação alcoólica. Oliva-Neto (1995) cita que os efeitos dos ácidos orgânicos sobre a levedura dependem de vários fatores como tipo e concentração do ácido e das leveduras usadas, sinergismo com outros produtos e pressão osmótica.

Segundo Maiorella et al (1983), o ácido láctico contém uma hidroxila extra, é muito menos solúvel em lipídeos do que os demais ácidos orgânicos e a inibição da levedura ocorre em concentrações mais elevadas (10-40 g/L). 
Nesse trabalho, os autores constataram um decréscimo de $80 \%$ na população de $S$. cerevisiae crescidas em meio sintético com $40 \mathrm{~g} / \mathrm{L}$ de ácido láctico. 


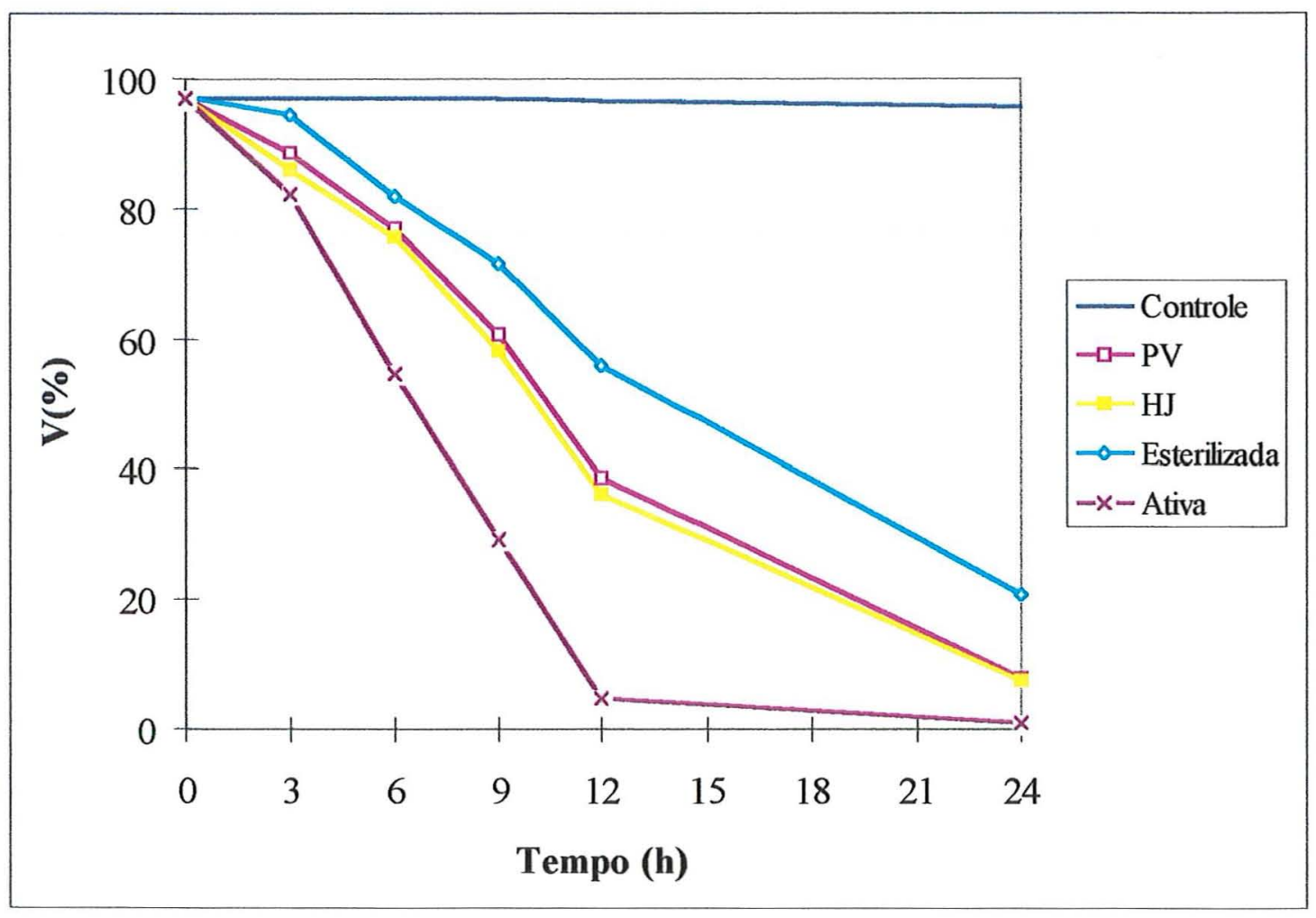

Figura 4. Viabilidade celular da levedura S. cerevisiae nos tratamentos controle, cultura mista ativa e inativadas por esterilização e pelos antibacterianos Kamoran $\mathrm{HJ}$ (HJ) e penicilina V potássica (PV). 


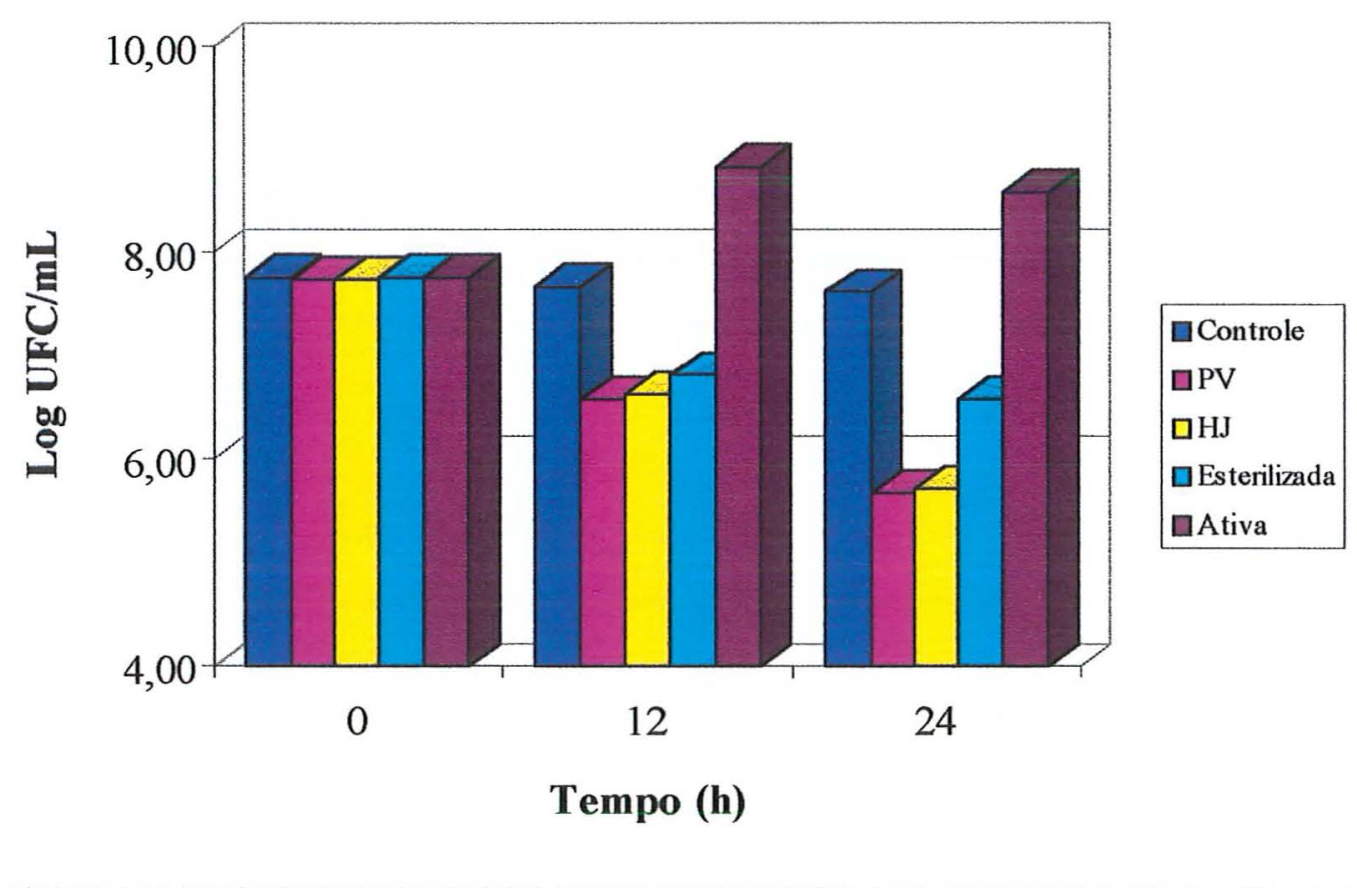

Figura 5. Avaliação do crescimento da levedura $S$. cerevisiae nos tratamentos controle, cultura mista inativada por esterilização, pelos antibacterianos Kamoram HJ (HJ) e penicilina $\mathrm{V}$ potássica $(\mathrm{PV})$ e cultura ativa (S. cerevisiae em cultura mista ativa com L.fermentum), expressos em Log UFC/mL. 
Tabela 14. Determinação de acidez ( $\mathrm{g}$ ácido láctico/L) e $\mathrm{pH}$ das culturas mistas ativa de S. cerevisiae e inativada por esterilização e pelos agentes antibacterianos Kamoran $\mathrm{HJ}$ e penicilina $\mathrm{V}$ potássica $^{(a)}$.

\begin{tabular}{|c|c|c|c|c|c|c|c|c|c|c|}
\hline \multirow[t]{2}{*}{ Tempo } & \multicolumn{2}{|c|}{ Controle } & \multicolumn{2}{|c|}{$\begin{array}{c}\text { Penicilina V } \\
\text { potássica }\end{array}$} & \multicolumn{2}{|c|}{$\begin{array}{c}\text { Kamoran } \\
\text { HJ }\end{array}$} & \multicolumn{2}{|c|}{$\begin{array}{l}\text { Inativada por } \\
\text { esterilização }\end{array}$} & \multicolumn{2}{|c|}{ Ativa } \\
\hline & Acidez & pH & Acidez & pH & Acidez & pH & Acidez & $\mathbf{p H}$ & Acidez & $\mathrm{pH}$ \\
\hline $0: 00$ & 6,36 & 4,47 & 10,74 & 3,96 & 10,80 & 3,91 & 11,52 & 3,86 & 14,01 & 3,61 \\
\hline $6: 00$ & 6,99 & 4,37 & 11,55 & 3,83 & 12,21 & 3,81 & 12,36 & 3,76 & 15,57 & 3,52 \\
\hline $12: 00$ & 7,47 & 4,34 & 11,82 & 3,83 & 12,42 & 3,79 & 13,02 & 3,74 & 16,14 & 3,49 \\
\hline $24: 00$ & 7,74 & 4,31 & 11,82 & 3,81 & 12,36 & 3,76 & 13,20 & 3,74 & 16,44 & 3,46 \\
\hline
\end{tabular}

${ }^{(a)}$ Média de 3 ensaios

\subsection{Efeito do tratamento enzimático sobre a capacidade floculante de $L$. fermentum}

A metodologia de adição dos flocos de enzimas na suspensão de microrganismos está descrita no item 3.7.2.

Após a adição das enzimas em culturas puras de $L$. fermentum e $S$. cerevisiae, as suspensões foram plaqueadas para se verificar a possivel ação das enzimas sobre os componentes protéicos da superficie celular das populações. Verificou-se que as enzimas não interferiram no crescimento da população, pois os resultados encontrados não diferiram do controle, nem para bactérias e nem para leveduras (Tabela 15). A presença e a atividade das 
enzimas não causou alterações na viabilidade celular da levedura, como também não afetou o crescimento de L. fermentum (Tabela 16).

Tabela 15. Viabilidade celular da cultura da levedura S. cerevisiae com a adição de enzimas do grupo peptidohidrolases ${ }^{(a)}$.

\begin{tabular}{ccc}
\hline Tratamento & Viabilidade (\%) & $\sigma$ \\
\hline Controle & 95,66 & $\pm 0,94$ \\
Papaína & 95,19 & $\pm 1,15$ \\
Bromelina & 95,17 & $\pm 1,15$ \\
Ficina & 95,49 & $\pm 1,14$ \\
\hline
\end{tabular}

(a) Média de 5 ensaios; viabilidade em \%

Tabela 16. População de L. fermentum após a adição das enzimas papaína, bromelina e ficina ${ }^{(a)}$.

\begin{tabular}{ccc}
\hline Tratamento & $\mathrm{UFC} / \mathbf{m L}^{(\mathrm{b})}$ & $\sigma$ \\
\hline Controle & $4,12 \times 10^{8}$ & $\pm 2,38 \times 10^{8}$ \\
Papaina & $4,14 \times 10^{8}$ & $\pm 1,81 \times 10^{8}$ \\
Bromelina & $3,54 \times 10^{8}$ & $\pm 1,49 \times 10^{8}$ \\
Ficina & $3,81 \times 10^{8}$ & $\pm 1,80 \times 10^{8}$
\end{tabular}

\footnotetext{
${ }^{(3)}$ Média de 3 ensaios (36 leituras cada)
}

${ }^{(b)}$ Unidade formadora de colônias 
As linhagens de L. fermentum utilizadas durante os experimentos nem sempre apresentaram capacidade de flocular $S$. cerevisiae. Com relação ao efeito floculante, durante o cultivo de L. fermentum, não foi possível caracterizar as linhagens floculantes das não floculantes através dos métodos analíticos empregados, pois os resultados obtidos foram muito semelhantes. Frederick (1994), estudando as características morfológicas e bioquímicas de L. fermentum envolvidos na floculação de leveduras concluiu que esta característica é instável e que diferentes linhagens dos cultivos analisados pertencentes a mesma espécie L. fermentum não apresentam diferenças significativas entre floculantes e não floculantes. É possível que este fenômeno esteja relacionado à composição e necessidade do microrganismo por alguns componentes disponíveis ou não no meio.

A redução da floculação pela ação das enzimas papaína, bromelina e ficina foi avaliada segundo Santos (1991) e as bactérias foram agrupadas de acordo com a capacidade de flocular, relacionada com as leituras em absorbância (Abs) sendo classificadas como:

- Não floculantes (Abs $>0,65)$

- Fracamente floculantes $(0,40<\mathrm{Abs}<0,65)$

- Fortemente floculantes (Abs $<0,40)$

Os resultados obtidos demonstraram um aumento da turbidez nas amostras onde foram aplicadas as enzimas, o que não ocorreu no controle, devido a sedimentação dos flocos (Figura 6). Isto vem reforçar os estudos sobre o fator responsável pela floculação, a qual aparenta ser de natureza 
protéica, como verificaram outros pesquisadores (Santos e Yokoya, 1992, Santos e Yokoya, 1993).

Avaliando as características da floculação de leveduras causada por $L$. fermentum, Santos e Yokoya (1993) observaram que as linhagens floculantes da bactéria possuíam moléculas de natureza protéica, intimamente ligadas à superficie da célula.

Particularmente para as bactérias, a função de flocular células de leveduras ao seu redor através de pontes protéicas não está elucidado. Entretanto, pode-se supor que esteja ligada a necessidade nutricional já que $L$. fermentum como outros lactobacilos, são microrganismos seqüenciais na deterioração de diversos substratos (Tilbury, 1975, Viana, 1989).

Para Bromberg (1994) a floculação estaria relacionada com um mecanismo intercelular, em nível da parede celular desses microrganismos, envolvendo componentes protéicos da superficie celular da bactéria, mais especificamente os grupos funcionais fenol e indol, e carboidratos da parede celular da levedura. E ainda que, embora o sistema de floculação de $S$. cerevisiae causada por L. fermentum, tenha sido classificado em seu trabalho de acordo com o modelo simbiótico, este pode ser enquadrado no modelo das lectinas, devido ao envolvimento do componente protéico da parede celular do microrganismo floculante.

Se o caráter floculante é de natureza protéica sendo afetado pela pronase conforme Yokoya e Santos (1993), então, alguma ação da proteína poderia efetivamente mostrar efeito sobre a floculação e também sobre o microrganismo causal. Procurou-se então testar preliminarmente diversas enzimas como pepsina, tripsina e outras, que se mostraram completamente inócuas ao efeito floculante e ao microrganismo. A ação desfloculante foi 
encontrada no grupo das peptidohidrolases de origem vegetal como a papaína, a bromelina e a ficina (Gould 1975; Gerhartz 1990).

Através dos estudos que apresentaram este caráter protéico da bactéria estar relacionado a mecanismos intercelulares em nível da parede celular, procurou-se avaliar se estas enzimas hidrolíticas poderiam ter causado algum efeito sobre a viabilidade da bactéria, o que não foi observado. Pelo plaqueamento das culturas tratadas verifica-se que a ação das enzimas não afetou o número de colônias, o que não elimina a hipótese de que o componente de natureza protéica da superficie celular da bactéria não tenha modificado o comportamento fisiológico da mesma. Isto pode estar relacionado com o que foi citado por Klaenhammer (1984) que, em seus estudos sobre a genética do gênero Lactobacillus, relatou a dificuldade encontrada para realizar lise celular da parede das bactérias com lizozima. No caso de levedura, existem citações do uso de papaína em floculação de leveduras (linhagens floculantes). Segundo Nishihara et al (1977) as proteinases como papaína, quimiotripsina e pepsina destróem irreversivelmente a capacidade floculadora em leveduras, fato que não ocorreu nos ensaios preliminares que foram realizados utilizando a papaína em floculação de leveduras de linhagem floculante.

O efeito obtido após a adição das enzimas na suspensão de microrganismos é demonstrado através das fotografias apresentadas nas Figuras 7 a 10 . 


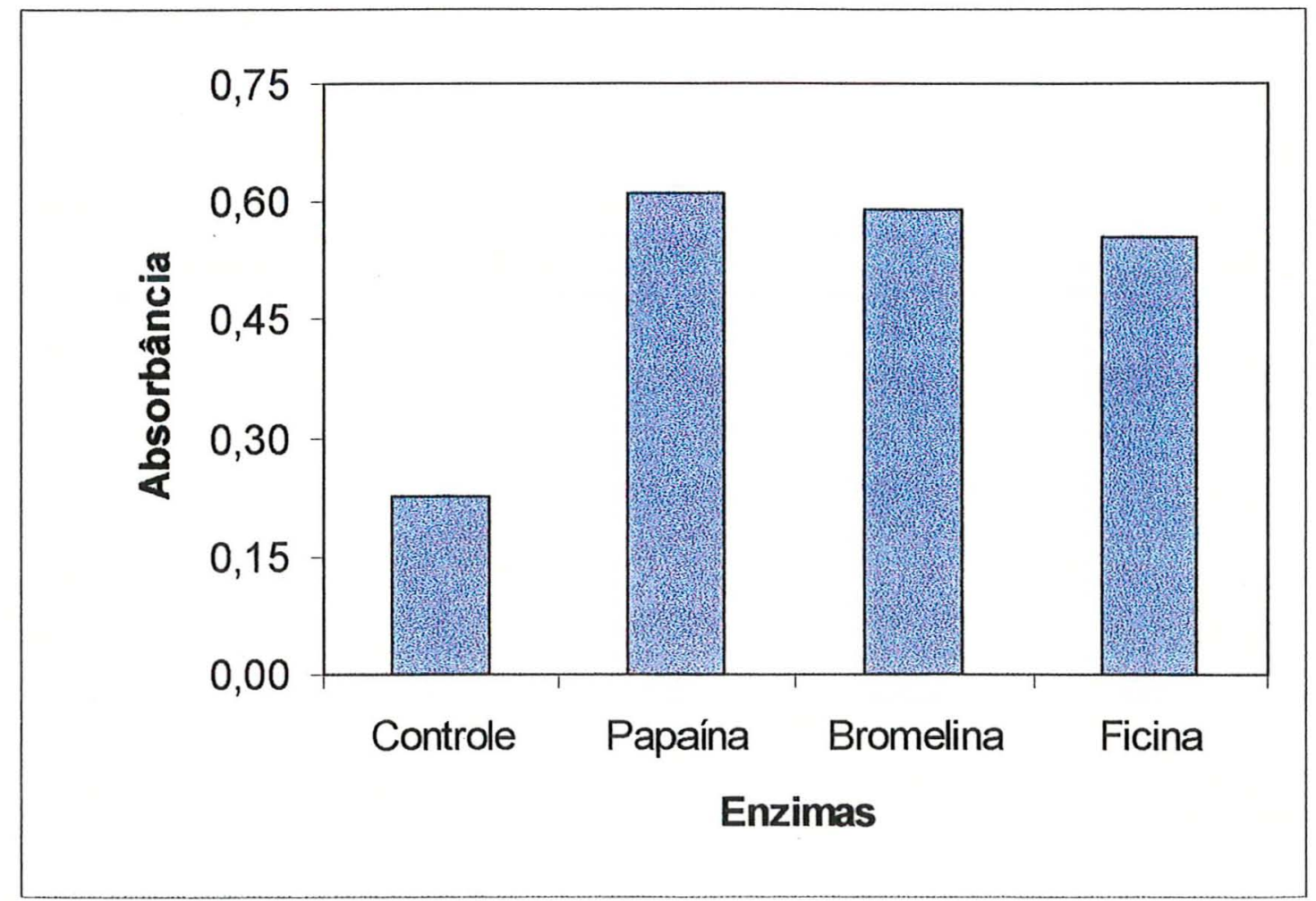

Figura 6. Determinação dos efeitos do tratamento enzimático sobre a floculação da levedura causada por L. fermentum, através de leituras espectrofotométricas, expressas em absorbância. 


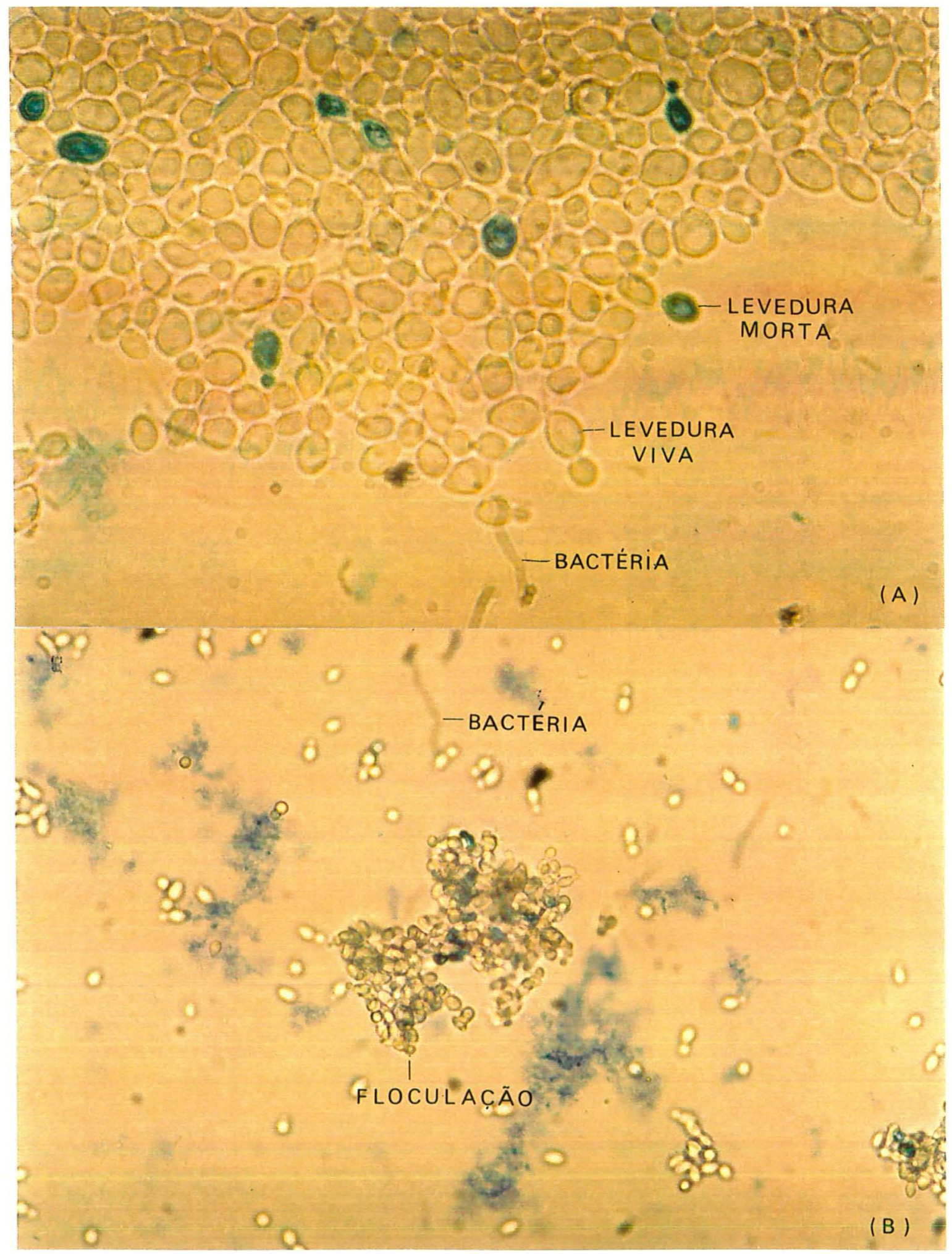

Figura 7. Floculação da levedura $S$. cerevisiae causada por L. fermentum $\left(\mathrm{x} 400^{(\mathrm{A})} \mathrm{e} \times 1000^{(\mathrm{B})}\right)$. 


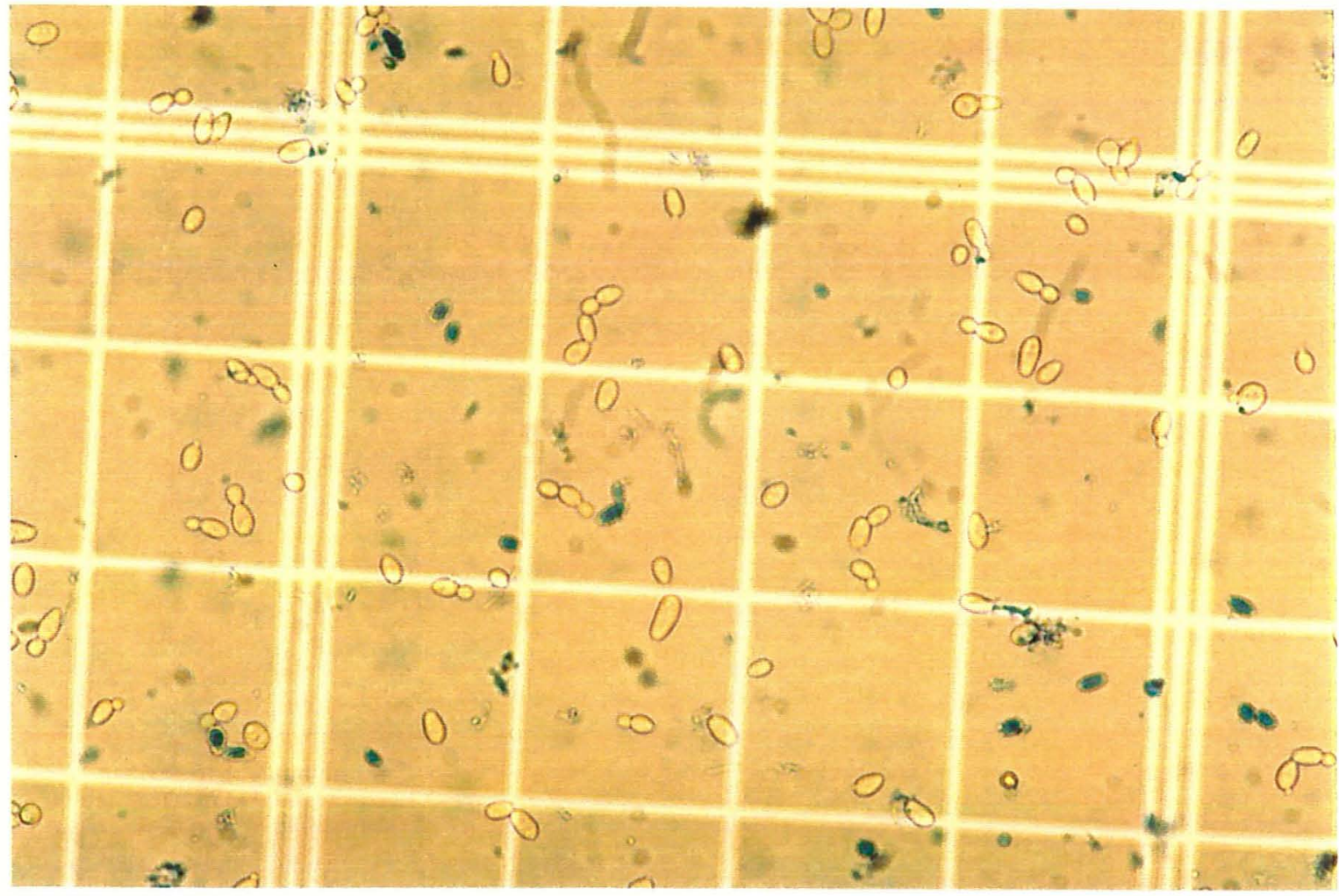

Figura 8. Efeitos da enzima papaína sobre a floculação da levedura

S. cerevisiae causada por L. fermentum (x 400). 


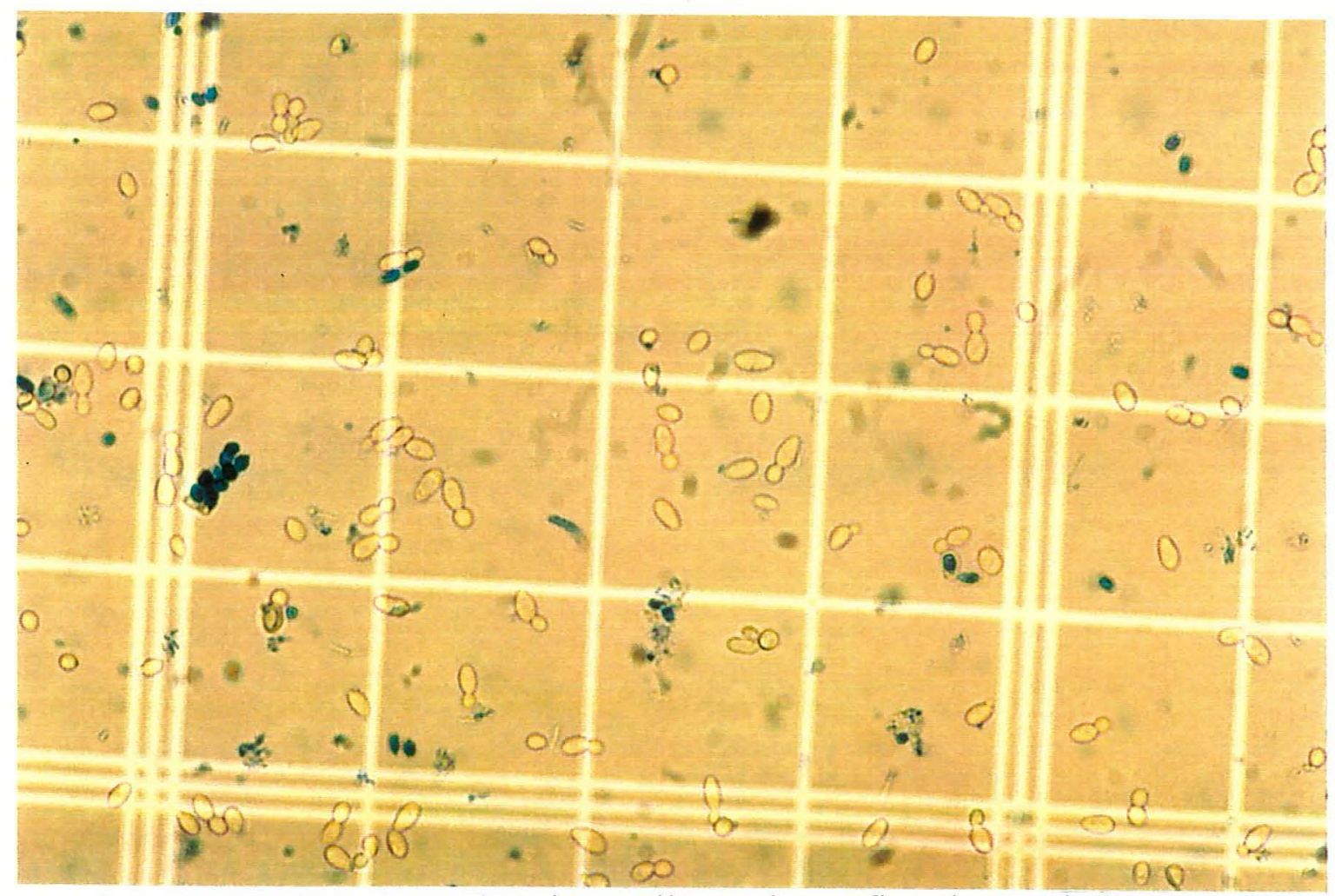

Figura 9. Efeitos da enzima bromelina sobre a floculação da levedura

S. cerevisiae causada por L. fermentum (x 400). 


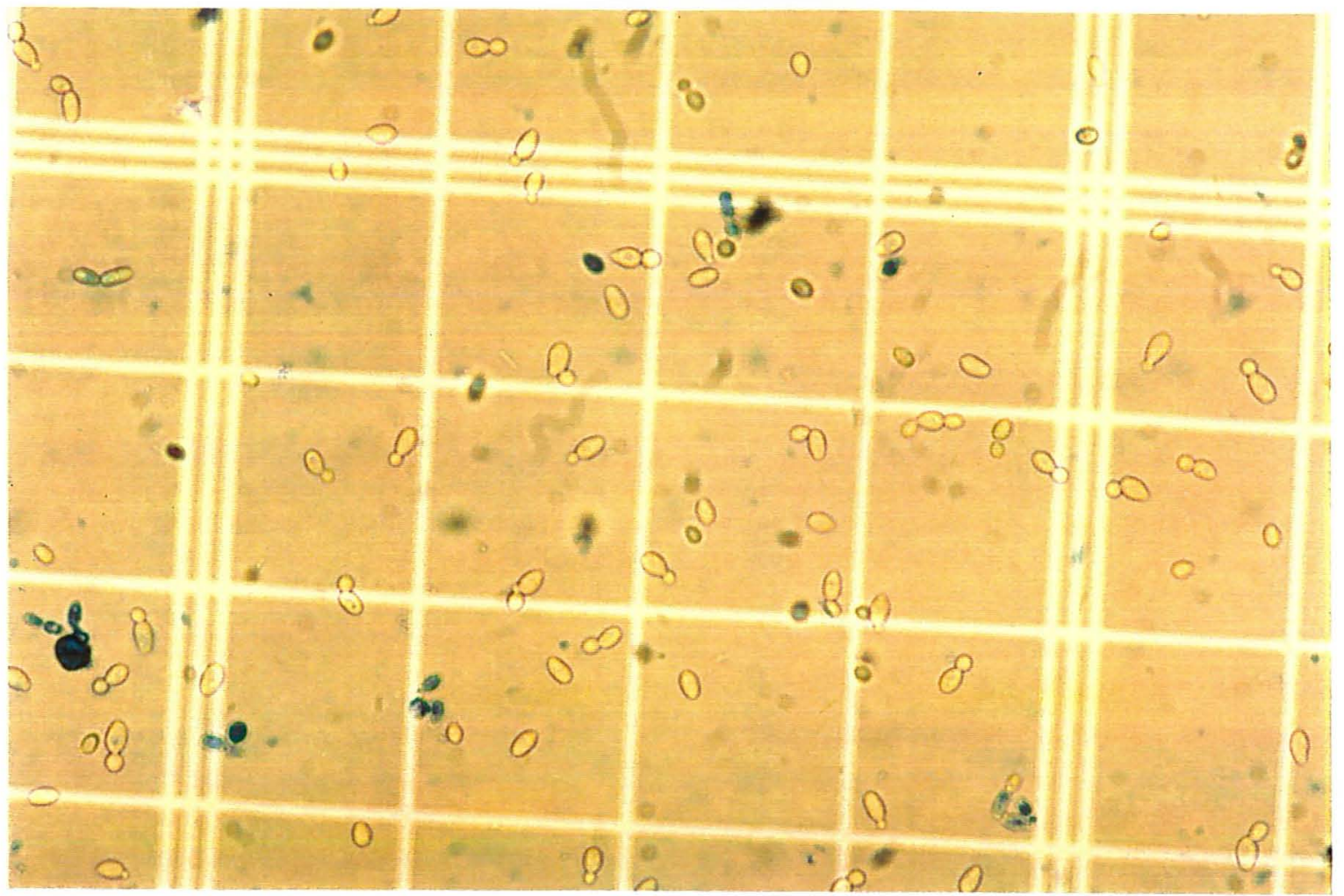

Figura 10. Efeitos da enzima ficina sobre a floculação da levedura

S. cerevisiae causada por L. fermentum (x400). 


\section{CONCLUSÕES}

- A metodologia de microplacas não apresentou diferença significativa quanto ao desenvolvimento dos microrganismos (L. fermentum e S. cerevisiae) em relação à técnica convencional de semeadura em profundidade, demonstrando que pode ser aplicada como técnica alternativa com vantagens desde que meios e condições sejam devidamente adaptados aos microrganismos que se deseja pesquisar.

- O meio de cultura de caldo de cana suplementado MCC-A apresentou-se totalmente adequado, proporcionando crescimento de colônias de $L$. fermentum semelhantes aos obtidos no meio MRS, podendo ser usado em substituição a este ao menos para as linhagens estudadas.

- A contaminação por L. fermentum mostra um fator importante além de causar floculação, pois tem grande influência sobre a viabilidade de $S$. cerevisiae, podendo reduzir a valores próximos a 0 em cerca de 12 horas após a fermentação completar-se para leveduras. 
- A inativação da cultura de L. fermentum mostrou que somente a presença de seus produtos metabólicos pode causar grandes prejuízos a fermentação, já que a toxidez de seus produtos resiste ao calor embora com atenuação de seu efeito.

- Enzimas do grupo das peptidohidrolases como a papaína, a bromelina e a ficina têm pronta ação sobre o componente protéico causal da floculação de S. cerevisiae provocada por L. fermentum. 


\section{REFERÊNCIAS BIBLIOGRÁFICAS}

ALCARDE, V., E. Avaliação de antimicrobianos na germinação de esporos e na multiplicação de bactérias isoladas de processos de fermentação alcoólica. Piracicaba, 1995. 114 p. Dissertação (Mestrado) - Escola Superior de Agricultura "Luiz de Queiroz", Universidade de São Paulo.

ALTHERTUM, F.; CRUZ, M.R. M.; VAIRO, M.L.R.; GAMBASSI, D.M. Efeito dos microrganismos contaminates da fermentação alcoólica nas microdestilarias. STAB. Açúcar Álcool e Subprodutos. v. 3, n. 1, p. 42-49, jan/fev. 1984.

AMERINE, M.A.; OUGH, C.S. Wine and must analysis. New York: John Wiley \& Sons. 1974. $121 \mathrm{p}$.

AMORIM, H.V.; OLIVEIRA, A.J. Infecção na fermentação: como evitá-la. Álcool e Açúcar, v.2, n.5, p.12-18, jul/ago. 1982.

BEVAN, D.; BOND, J. Microorganism in field and miel - A preliminary survey. In: QUEENSLAND SOCIETY OF SUGAR CANE TECNOLOGISTS, 38:, Cairns, 1971. Proceedings, Brisbane: Watson Ferguson, 1971, p.137-143. 
BREED, R.S.; MURRAY, E.G.D.; SMITH, N.R. Bergey's manual of determinative bacteriology, 7.ed. Baltimore: The Willians \& Wilkins, 1957. p.541-554.

BROMBERG, R. Estudo do mecanismo de floculação de leveduras causada por Lactobacillus fermentum. Campinas, 1994. 86 p. Dissertação (Mestrado)- Faculdade de Engenharia de Alimentos, Universidade Estadual de Campinas.

BRYAN-JONES, G. Lactic acid bacteria in distillery fermentations. In: CARR, J.G.; CUTTING, C.V.; WHITING, G.C. Lactic acid bacteria in beverages and foods. London: Academic Press, 1973. cap.5, p.165-175.

BUSTA, F.F.; PETERSON, E.H.; ADAMS D.M.; JOHNSON M.G. Colony count methods. In: SPECK, M.L. Compendium of methods for the microbiological examination of foods. 2.ed. Washington: American Public Health Association, 1984. cap.4, p.62-83

CALLEJA, G.B. Cell aggregation. In: ROSE, A.H.B.; HARRISON, J.S.; The Yeast. 2 ed. London: Academic Press, 1987. v.2, p.165-238.

CALLEJA, G.B.; JOHNSON, B.F. A comparison of quantitative methods for measuring yeast flocculation. Canadian Journal Microbiology, v. 3, n.1, p.68-74, 1977. 
CAMARGO, C.A.; USHIMA, A.H.; RIBEIRO, A.M.M.; SOUZA, M.E.P.; SANTOS, N.F. Manual de Recomendações: conservação de energia na indústria do açúcar e do álcool., São Paulo: Instituto de Pesquisas Tecnológicas, 1990, p.31 - 41.

CHIN, P.M. ; INGLEDEW, W.M. Effect of lactic acid bacteria on wheat mash fermentation prepared with laboratory backset. Enzyme Microbial and Technology, v.16, n.4, p.311-317, April, 1994.

CONTROLE microbiológico da usina de açúcar e álcool. Boletim Técnico Copersucar. n.22, p.2-17, 1983.

COOPERATIVA DE PRODUTORES DE CANA, AÇƯCAR E ÁLCOOL DO ESTADO DE SÃO PAULO. Centro de Tecnologia. Divisão Industrial. Fermentação. São Paulo: Copersucar, 1987. 434 p.

DELGADO, A.A.; Efeito da queima dos canaviais. STAB. Açúcar Álcool e Subprodutos, v.3, n.6, p.42-45, jul/ago. 1985.

DEMETER, K. J. Lactobacteriologia. Zaragoza: Acriba. 1969. 331 p.

DIFCO Manual. Dehidrated culture media and reagents for microbiology. 10.ed. Detroit: DIFCO Laboratories, 1984. 1155p. 
EGUCHI, S.Y. Agentes antimicrobianos In: EGUCHI S.Y.; YOKOYA, F.; CANHOS V.P.; GALLO, C.R. Pontos críticos microbiológicos em usinas de açúcar e álcool. Campinas: Fundação Tropical de Pesquisas Tecnologicas André Tosello, 1989. p.1-22.

FIGUEIREDO, R.M. Alguns produtos obtidos por fermentação lática. Piracicaba: ESALQ. Departamento de Ciência e Tecnologia Agroindustrial, 1989. p.2-8.

FREDERICK, M. K. B. Estudo genético, fisiológico e molecular de Lactobacillus fermentum envolvidos na floculação de leveduras. Campinas, 1994. 56p. Dissertação (Mestrado)-Faculdade de Engenharia de Alimentos, Universidade Estadual de Campinas.

GALLI, Z. F. Fermentação do mel final das usinas de Piracicaba. II Semana de fermentação alcoólica. Piracicaba: Instituto Zimotécnico, 1961. v. 2, p.297-304.

GALLO, C.R.; CANHOS, V.P. Contaminantes na fermentação alcoólica Revisão. STAB. Açúcar, Álcool e Subprodutos, v.9, n. 4/5, p.35-39, mar/jun. 1991.

GALLO, C.R.; CANHOS, V.P.; Efeito do tratamento ácido no fermento sobre a microbiota bacteriana contaminante da fermentação alcoólica. STAB. Açúcar, Álcool e Subprodutos, v.9, n.6, p.35-39, jul/ago. 1991. 
GALLO, C.R. Determinação da microbiota bacteriana de mosto e de dornas de fermentação alcoólica. Campinas, 1990. 388 p. Tese (Doutorado)Faculdade de Engenharia de Alimentos, Universidade Estadual de Campinas.

GALLO, C.R. Identificação de bactérias contaminantes da fermentação alcoólica. STAB. Açúcar, Álcool e Subprodutos. v.10, n.5, p. 30-34, mai/jun. 1992.

GERHARTZ, W. Enzymes in industry - production and applications. New York: VCH Publishers, 1990. p.119-121.

GILLILAND, R.P.; LACEY, J.P. Lethal action by an Acetobacter on yeasts. Nature, v.202, p. 727-728, May 1964.

GOULD B.J. Enzyme biotechnology. London: Ellis Horwood Limited, 1975. p.147-149.

GUTIERREZ, L.E., AMORIN, H.V.;BASSO, L.C. Inibidores da fermentação alcoólica. STAB. Açúcar, Álcool e Subprodutos, v.9, n.6, p. 24 -30, jul/ago. 1991.

GUTIERREZ, L.E., Composição em ácidos graxos e viabilidade celular em Saccharomyces cerevisiae. STAB. Açúcar, Alcool e Subprodutos, v.9, n.6, p. 31-34, jul/ago. 1991. 
HARTY, D.W.S.; PATRIAKAKIS, M.; HUME, E.B.H.; OAKEY, H. J.; KNOX, K.W. The aggregation of human platelets by Lactobacillus species. Journal of General Microbiology, v.139, n. 10, p.2945-2951, 1993.

HONIG, G.P. Princípios de tecnologia azucareira. México(D.F.): Ed. Continental. 1969. v.2. 449 p.

HORII, J. Isolamento e contagem de bactérias contaminantes do caldo de cana em meio de cana e PCA. In: SEMINÁRIO AGROINDUSTRIAL "LUIZ DE QUEIROZ", 2., s.n.t.

INSTITUTO ADOLFO LUTZ. Normas analíticas do Instituto Adolfo Lutz: volume 1- Métodos químicos e físicos para a análise de alimentos. 3.ed. São Paulo, 1985. 533 p.

KAJI, D.A.; CANHOS, V.P. Contaminantes do processo de produção de açúcar e álcool. In: EGUCHI S.Y.; YOKOYA, F.; CANHOS V.P.; GALLO, C.R. Pontos críticos microbiológicos em usinas de açúcar e álcool. Campinas: Fundação Tropical de Pesquisas Tecnologicas André Tosello, 1989. p.1-9.

KANEKO T; YAMAMOTO, Y. Killing of yeast by acetic acid bacteria. Journal of the Institute of Brewing, v.74, n.5, 1968. p. 476.

KLAENHAMMER, T.R. A general method for plasmid isolation in lactobacilli. Current Microbiology, v. 10, p.23-28, 1984. 
LEÃO, C.; VAN UDEN, N. Effects of ethanol and other alkanols on kinetics and the activation parameters of thermal death in Saccharomyces cerevisiae. Biotechnology and Bioengineering, v.24, n.7, p.1581-1590, 1982.

LIMA U. A.; AQUARONE, E.; BORZANI W. Tecnologia de Fermentações. São Paulo: Edgard Blucher, 1975. v. 1, 286 p. (Biotecnologia, 2).

LOPES, J.J.C. Efeito do complexo broca/podridão na fermentação alcoólica de caldo de cana-de-açúcar. STAB. Açúcar, Álcool e Subprodutos, v.1, n.3, p.40-44, jan/fev. 1983.

MAIORELlA, B.; BLANCH, H.W.; WILKE, C.R. By-product inhibition effects on ethanolic fermentation by Saccharomyces cerevisiae. Biotechnology and Bioengineering, v.23, n.1, p.103-121. 1983.

MAKANJIOLA, D.B.; TYMON, A.; SPRINGHAM, D.G. Some effects of lactic acid bacteria on laboratory-scale yeast fermentation. Enzyme Microbiology and Technology, v. 14, n. 4, p. 350-357, 1992.

MERCK. Reativos, diagnóstica, produtos químicos. Frankfurter: Ed. Merck. 1992/93. $1584 \mathrm{p}$.

MILL, P.J. The nature of interactions of flocculent cells in the flocculation of Saccharomyces cerevisiae. Journal of General Microbiology, v. 3, n.1, p. 61-68, 1964. 
MURIANA, P.M.; KLAENHAMMER, T.R. Purification and partial characterization of lactacin $\mathrm{F}$ a bacteriocin produced by Lactobacillus acidophillus 1108. Applied and Environmental Microbiology, v.57, n.1, p.114-121, 1991.

NAGODAWITHANA, T.W.; STEINKRAUS, K. Influence of the rate of ethanol prodution and accumulation on the viability of Saccharomyces cerevisiae in "rapid fermentation". Applied and Environmental Microbiology, v.31, n.2, p.158, 1976.

NAMBA, A.; NISHIZAWA, Y.T.; TSUCHIYA, Y.; NAGAI, S. Kinetic analysis for batch ethanol fermentation of Saccharomyces cerevisiae. Journal Fermentation Technology. v. 65, n.3, p.277-283, 1987.

NEDER, N.R. Microbiologia de alimentos I. Piracicaba: ESALQ/Depto de Ciência e Tecnologia de Alimentos, 1992. 149 p.

NEISH, A. C. Determination of reducing sugars. In: NATIONAL RESEARCH COUNCIL OF CANADA. Analytical methods for bacterial fermentations. 2.ed. Saskatoon, 1952. p.34.

NISHIHARA, H.; TORAYA, T. ; FUKUI, S. Effect of chemical modification of cell components of a brewer's yeast on the forming ability. Archives of Microbiology, v.115, n.1, p.19-23, 1977. 
NISHIHARA, H.; TORAYA, T. ; FUKUI, S. Flocculation of cell walls of brewer's yeast and effects of metal ions, protein denaturants and enzyme treatments. Archives of Microbiology, v. 131, n.2, p.112-115, 1982.

OLIVA-NETO, P. Influência da contaminação por bactérias láticas na fermentação alcoólica pelo processo de batelada alimentada. Campinas, 1990. 207 p. Dissertação (Mestrado)- Faculdade de Engenharia de Alimentos, Universidade Estadual de Campinas.

OLIVA-NETO, P. Estudo de diferentes fatores que influenciam o crescimento da população bacteriana contaminate da fermentação alcoólica por leveduras. Campinas, 1995. 183 p. Tese (Doutorado)- Faculdade de Engenharia de Alimentos, Universidade Estadual de Campinas.

OLIVEIRA, A.J.; GALLO, C.R.; ALCARDE, V.E.; GODOY, A; AMORIM, H.V. Métodos para o controle microbiológico na produção de açúcar e álcool. Piracicaba: FERMENTEC/ FEALQ/ESALQ, 1996. 89 p.

PELCZAR, M.; REID, R.; CHAN, E.C.S. Microbiologia. São Paulo: McGraw-Hill, 1981. v.1, 566 p.

PITTA, R.C.M.; HORII, J. Estudos do efeito de ácido sulfúrico Busan 887 sobre a população microbiana do caldo de cana. Botucatu, 1986. 18 p. Instituto Básico de Biologia Médica e Agricola, Universidade Estadual Paulista. 
PRÄVE, P., FAUST, U; SITTIG, W.; SUKATSCH, D.A. Fundamentals of biotechnology. Weinhein: VCH Verlagsgesellschaft, 1987. 792 p.

RODINI, M.A.T. Isolamento, caracterização e identificação de bactérias contaminantes de dornas de fermentação nas destilarias de etanol. Piracicaba, 1985. 92p. Dissertação (Mestrado) - Escola Superior de Agricultura "Luiz de Queiroz",Universidade de São Paulo.

ROSALES, S.Y.R. Contaminantes bacterianos da fermentação etanólica: isolamento em meios diferenciais, identificação e avaliação de desinfetantes. Rio Claro, 1989. 200p. Tese (Doutorado)- Instituto de Biociências, Universidade Julio de Mesquita Filho.

SANTOS, M.T. Características da floculação de leveduras causadas por Lactobacillus fermentum. Campinas, 1991. 93p. Dissertação (Mestrado)Faculdade de Engenharia de Alimentos, Universidade Estadual de Campinas.

SANTOS, M.T.; YOKOYA, F. Characteristics of yeast cell flocculation by Lactobacillus fermentum. Journal of Fermentation and Bioenginnering, v. 75, n. 2, p. $151-154,1993$.

SANTOS, W.L.M.; SOUZA, R.M.; RIBEIRO, R.M.P.; CARVALHO, C.R.; PRADO, C. S. Bacteriocinas: definição e características. Higiene Alimentar, v.8, n.34, p.21-25, 1994. 
SERRA, G.E.; CEREDA, M.P.; FERES, R.J.F.; BERTOZO, M. T.; VICENTE, A.L. Contaminação da fermentação alcoólica "floculação do fermento". Brasil Açucareiro, v.93, n.6, p. 26-31, jun. 1979.

SERRA, G.E., CEREDA, M.P.; PINTO, S.Z.;. MENEGUIM M.A ; MARINO, E.A.; FERREIRA, L.J.; BERTHIOL A.E. Controle microbiológico da fermentação alcoólica em condições industriais. In: SIMPÓSIO DE TECNOLOGIA DO AÇÚCAR E DO ÁlCOOL,3., Águas de São Pedro, 1980. Anais. Águas de São Pedro: STAB, 1980. p. 287-295.

SERRA, G. E., CEREDA, M. P., CAGLiARI, A. M. MENEGUIM, M. A. Métodos microbianos de avaliação de antissépticos empregados em indústrias alcooleiras. Brasil Açucareiro, v.97, n.3, p. 44-50, mar, 1981.

SHARPE, A.N.; KILSBY, D.C. A rapid inexpensive bacterial count technique using agar droplets. Journal of Applied Bacteriology, v.34, n.2, p. 435$441,1971$.

SILVA, M.H.; Controle da inversão no caldo de cana. Sugar y Azucar, v.69, n.25, p.61-68, 1974.

STRATFORD, M.; KEENAN, H.J. Yeast flocculation: quantitation. Yeast, v.4, p.107-115. 1988. 
STRATFORD, M. Lectin-mediated aggregation of yeast - yeast flocculation. Biotechnology General Enginnering Reviews. v.10, n.2, p.283-341, $1992 b$.

STRATFORD, M. Yeast flocculation: reestructuring the theories in line with recent research. Cerevisiae. v. 21, n. 4, p. 38-45, 1996.

STUPIELLO, M.G. Avaliação de metodologia para estudo da ação de alguns antimicrobianos frente as bactérias gram $(+)$ isoladas da fermentação alcoólica. Piracicaba, 1993. 96 p. Dissertação (Mestrado)- Escola Superior de Agricultura "Luiz de Queiroz", Universidade de São Paulo.

TAGG, J.R.; DAJANI, A.S.; WANNAMAKER, L.W. Bacteriocins or grampositive bacteria. Bacteriological Reviews, v. 40, n.3, p.722-756, 1976.

THATCHER, F.S.; CLARK, D.S. Microorganisms in foods: their significance and methods of enumerations. 1st ed. Toronto: University Toronto Press, 1968. $321 \mathrm{p}$.

TILBURY, R.H. Occurence and effect of lactic acid bacteria in the sugar industry. In : CARR, J.G.; CUTTING, C.V.; WHITING, G.C. Lactic acid bacteria in beverages and food. New York: Academic Press, 1975 p.177191. 
TILBURY, R.H.; HOLLINGSWORTH, B.S.; GRAHAM, S.D.; POTTAGE, P. Mill sanitation - A fresh approach to biocide evaluation. In: INTERNATIONAL SOCIETY OF SUGAR CANE TECHNOLOGISTS, 16., São Paulo. 1977. Proceedings. São Paulo: ISSCT, 1977. v. 3, p. 2749-2768.

VIANA, Z.C.V. Estudo comparativo entre Candida parapsilosis var. intermedia (IZ-A7) e leveduras naturais da "goga" (Mel de cacau), que produzem um fator com capacidade de inibir o crescimento do fungo Phytophtora capsici. Piracicaba, 1989. 64 p. Dissertação (Mestrado)- Escola Superior de Agricultura “Luiz de Queiroz”, Universidade de São Paulo.

YOKOYA, F. Microbiologia do processo de fermentação. In: EGUCHI S.Y.; YOKOYA, F.; CANHOS V.P.; GALLO, C.R. Pontos críticos microbiológicos em usinas de açúcar e álcool. Campinas: Fundação Tropical de Pesquisas Tecnologicas André Tosello, 1989. p.1-22.

YOKOYA, F. Problemas com contaminantes na fermentação alcoólica, STAB. Açúcar, Álcool e Subprodutos, v.9, n.6, p.38-39, jul/ago. 1991.

YOKOYA, F.; OLIVA-NETO, P. Características da floculação de leveduras por Lactobacillus fermentum. Revista de Microbiologia, v.22, n.1. p. 1216, 1991.

ZARATINI, R.A., WILLIANS, J.W., ERNANDES, J.R. Bacterial - induced flocculation in selected brewing strain of Saccharomyces cerevisisae. Cerevisiae and Biotechnnology, v.18, n.4, p. 65-70, 1993. 


\section{APÊNDICE}




\section{APÊNDICE 1. Metodologias alternativas de contagem e cultivo}

Resultados dos plaqueamentos pelas técnicas de semeadura em profundidade e microplacas, na contagem de colônias de Lactobacillus fermentum, expressos em UFC/mL.

\begin{tabular}{ccccc}
\hline Técnica & Ensaio & Diluição & $\mathbf{N}^{\mathbf{0}}$ de Colônias & UFC/ML \\
\hline Microplacas $^{(\mathrm{a})}$ & 1 & $10^{7}$ & $13,12,11,14,14,14,13,14,12,15,10,12$. & $1,28 \times 10^{9}$ \\
Profundidade $^{(\mathrm{b})}$ & & $10^{7}$ & $122,120,103,117,133,111,112,98,99$, & $1,15 \times 10^{9}$ \\
& 2 & $10^{7}$ & $10,12,11,11,11,10,11,13,10,11,10,11$. & $1,10 \times 10^{9}$ \\
Microplacas & & $10^{7}$ & $100,106,108,104,111,107,110,120,119$, & $1,11 \times 10^{9}$ \\
Profundidade & & & $103,122,127$. & \\
& & $10^{7}$ & $19,19,18,16,17,18,17,18,14,15,16,15$. & $1,67 \times 10^{9}$ \\
Microplacas & 3 & $10^{7}$ & $177,168,157,162,165,171,172,167,151$, & $1,65 \times 10^{9}$ \\
Profundidade & & & $166,172,163$, & \\
\hline
\end{tabular}

Média de 36 leituras 
Resultados dos plaqueamentos pelas técnicas de semeadura em profundidade e microplacas, na contagem de colônias de $S$. cerevisiae, expressos em $\mathrm{UFC} / \mathrm{mL}$.

\begin{tabular}{|c|c|c|c|c|}
\hline Técnica & Ensaio & Diluição & Nº de Colônias & UFC/ML \\
\hline Microplacas $^{(a)}$ & 1 & $10^{4}$ & $14,13,11,14,13,14,13,11,12,12,13,13$ & $1,27 \times 10^{6}$ \\
\hline Profundidade ${ }^{(b)}$ & & $10^{4}$ & $\begin{array}{l}134,138,137,128,130,120,129,132,134 \\
121,120,129\end{array}$ & $1,19 \times 10^{6}$ \\
\hline Microplacas & 2 & $10^{4}$ & $37,36,33,33,31,34,30,31,34,35,34,31$ & $3,31 \times 10^{6}$ \\
\hline Profundidade & & $10^{5}$ & $39,41,32,33,29,34,33,36,31,31,39,37$ & $3,31 \times 10^{6}$ \\
\hline Microplacas & 3 & $10^{4}$ & $33,30,30,32,33,31,30,32,35,35,31,32$ & $3,20 \times 10^{6}$ \\
\hline Profundidade & & $10^{5}$ & $28,30,28,26,31,37,33,32,38,36,32,34$ & $3,21 \times 10^{6}$ \\
\hline
\end{tabular}

(a ${ }^{\mathrm{eb}}$ Média de 36 leituras 
Resultados dos plaqueamentos de L. fermentum nos meios MRS-A e MCCA, através da metodologia de microplacas.

\begin{tabular}{ccccc}
\hline Meio & Ensaio & Diluição & $N^{\mathbf{o}}$ de Colônias & UFC/ML \\
\hline MRS-A $^{(\text {a) }}$ & 1 & $10^{7}$ & $40,34,41,40,38,35,41,32,39,34,35,37$. & $3,71 \times 10^{9}$ \\
MCC-A ${ }^{(b)}$ & & $10^{7}$ & $35,38,41,31,39,38,40,34,35,37,38,42$. & $3,78 \times 10^{9}$ \\
MRS-A & 2 & $10^{7}$ & $46,51,46,43,44,46,48,50,52,47,45,46$. & $4,70 \times 10^{9}$ \\
MCC-A & & $10^{7}$ & $46,44,47,52,49,52,47,50,49,47,49,51$. & $4,85 \times 10^{9}$ \\
MRS-A & 3 & $10^{6}$ & $35,41,45,43,47,43,40,46,40,47,36,45$. & $4,23 \times 10^{8}$ \\
MCC-A & & $10^{6}$ & $40,45,41,44,41,37,39,43,42,41,39,41$. & $4,13 \times 10^{8}$ \\
MRS-A & 4 & $10^{7}$ & $44,41,40,41,39,43,42,40,42,37,41,43$. & $4,12 \times 10^{9}$ \\
MCC-A & & $10^{7}$ & $42,38,39,42,39,44,44,41,38,38,40,43$. & $4,06 \times 10^{9}$ \\
MRS-A & 5 & $10^{7}$ & $25,27,29,26,26,26,27,26,24,23,27,26$. & $2,60 \times 10^{9}$ \\
MCC-A & & $10^{7}$ & $25,26,27,28,30,25,26,26,30,29,26,29$. & $2,72 \times 10^{9}$ \\
\hline (a) b) Média de 36 leituras & & & \\
\hline
\end{tabular}




\section{APÊNDICE 2. Cultivo de $L$. fermentum em meio de cultura MCC}

Avaliação do desenvolvimento de $L$. fermentum em meio de cultura MCC, determinado por análise turbidimétrica e expresso em \% Transmitância.

\begin{tabular}{cccccccc}
\hline Tempo (h) & $\mathbf{1}$ & $\mathbf{2}$ & $\mathbf{3}$ & $\mathbf{4}$ & $\mathbf{5}$ & $\mathbf{6}$ & $\mathbf{7}$ \\
\hline $0: 00$ & 80,9 & 80,5 & 82,7 & 82,8 & 84,3 & 81,2 & 82,8 \\
$3: 00$ & 78,3 & 79,0 & 80,0 & 79,1 & 79,0 & 80,4 & 79,4 \\
$6: 00$ & 74,6 & 72,8 & 77,6 & 78,8 & 76,7 & 75,3 & 74,5 \\
$9: 00$ & 44,8 & 40,9 & 41,5 & 41,5 & 42,6 & 47,3 & 46,5 \\
$12: 00$ & 14,6 & 14,2 & 15,3 & 12,0 & 14,5 & 13,9 & 12,5 \\
$24: 00$ & 7,9 & 8,1 & 7,8 & 7,9 & 7,9 & 7,7 & 8,1 \\
$27: 00$ & 7,9 & 8,1 & 7,8 & 8,0 & 7,8 & 7,7 & 8,1 \\
$30: 00$ & 7,9 & 8,1 & 7,7 & 7,9 & 7,6 & 7,6 & 8,0 \\
\hline
\end{tabular}

Resultados dos plaqueamentos de L. fermentum em meio de cultura MCC (UFC/mL).

\begin{tabular}{cccccccc}
\hline Tempo(h) & $\mathbf{1}$ & $\mathbf{2}$ & $\mathbf{3}$ & $\mathbf{4}$ & $\mathbf{5}$ & $\mathbf{6}$ & $\mathbf{7}$ \\
\hline $0: 00$ & $5,39 \times 10^{6}$ & $8,32 \times 10^{6}$ & $4,50 \times 10^{6}$ & $5,74 \times 10^{6}$ & $3,70 \times 10^{6}$ & $6,85 \times 10^{6}$ & $6,40 \times 10^{6}$ \\
$6: 00$ & $7,21 \times 10^{7}$ & $1,02 \times 10^{8}$ & $6,33 \times 10^{7}$ & $6,60 \times 10^{7}$ & $4,85 \times 10^{7}$ & $8,94 \times 10^{7}$ & $8,50 \times 10^{7}$ \\
$12: 00$ & $5,74 \times 10^{8}$ & $7,38 \times 10^{8}$ & $4,70 \times 10^{8}$ & $4,85 \times 10^{8}$ & $6,05 \times 10^{8}$ & $5,87 \times 10^{8}$ & $2,30 \times 10^{8}$ \\
$24: 00$ & $4,89 \times 10^{8}$ & $6,29 \times 10^{8}$ & $4,65 \times 10^{8}$ & $3,90 \times 10^{8}$ & $4,75 \times 10^{8}$ & $3,92 \times 10^{8}$ & $1,30 \times 10^{8}$ \\
\hline
\end{tabular}




\section{APÊNDICE 3. Resultados dos ensaios utilizando culturas mistas}

Resultados das análises de viabilidade celular da levedura S. cerevisiae (\%) em cultura mista com bactéria ativa.

\begin{tabular}{|c|c|c|c|c|c|c|c|c|c|c|}
\hline Tempo & 1 & 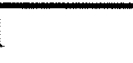 & & & 3 & & & & & 5 \\
\hline & Cont. $^{\text {(a) }}$ & Ativa $^{(b)}$ & Cont. & Ativa & Cont. & Ativa & Cont. & Ativa & Cont. & Ativa \\
\hline $0: 00$ & 96,25 & 96,78 & 97,48 & 96,28 & 96,59 & 96,54 & 97,66 & 97,65 & 96,85 & 96,56 \\
\hline $3: 00$ & 98,49 & 87,38 & 97,33 & 86,83 & 95,96 & 83,05 & 97,38 & 85,91 & 96,57 & 85,09 \\
\hline $6: 00$ & 96,94 & 53,56 & 97,21 & 52,09 & 96,03 & 52,05 & 97,41 & 58,30 & 96,60 & 53,78 \\
\hline 9:00 & 96,12 & 10,75 & 96,98 & 12,77 & 95,84 & 13,14 & 97,48 & 10,94 & 96,78 & 9,56 \\
\hline $12: 00$ & 96,11 & 2,21 & 96,72 & 4,21 & 95,81 & 1,68 & 96,94 & 3,44 & 96,02 & 2,95 \\
\hline
\end{tabular}

${ }^{(a)}$ Controle

${ }^{\text {(b) }}$ Cultura mista com a bactéria ativa

Resultados dos plaqueamentos no tratamento cultura mista ativa, expressos em UFC/mL.

\begin{tabular}{ccccccc}
\hline Tempo (h) & Amostra & $\mathbf{1}$ & $\mathbf{2}$ & $\mathbf{3}$ & $\mathbf{4}$ & $\mathbf{5}$ \\
\hline $0: 00$ & Bactéria & $4,90 \times 10^{7}$ & $3,72 \times 10^{8}$ & $3,90 \times 10^{8}$ & $2,83 \times 10^{8}$ & $3,87 \times 10^{8}$ \\
& Controle & $5,46 \times 10^{7}$ & $1,00 \times 10^{8}$ & $4,73 \times 10^{7}$ & $7,22 \times 10^{7}$ & $6,45 \times 10^{7}$ \\
\multirow{2}{*}{$12: 00$} & Cult. Mista & $3,93 \times 10^{8}$ & $6,74 \times 10^{7}$ & $1,13 \times 10^{8}$ & $8,71 \times 10^{7}$ & $1,86 \times 10^{8}$ \\
& Controle & $4,68 \times 10^{7}$ & $1,00 \times 10^{8}$ & $5,80 \times 10^{7}$ & $6,74 \times 10^{7}$ & $5,35 \times 10^{7}$ \\
& & & & & & \\
\hline
\end{tabular}


Resultados das análises de viabilidade celular da levedura S. cerevisiae (\%) em cultura mista inativada por esterilização.

\begin{tabular}{cccccccccccc}
\hline Tempo (h) & \multicolumn{1}{c}{$\mathbf{1}$} & \multicolumn{2}{c}{$\mathbf{2}$} & \multicolumn{3}{c}{$\mathbf{3}$} & \multicolumn{3}{c}{$\mathbf{4}$} & \multicolumn{2}{c}{$\mathbf{5}$} \\
\hline & Cont. $^{(\mathbf{a})}$ & Est. $^{(\text {b) }}$ & Cont. & Est. & Cont. & Est. & Cont. & Est. & Cont. & Est. \\
$0: 00$ & 96,72 & 96,45 & 97,91 & 97,56 & 97,24 & 96,95 & 98,00 & 97,53 & 96,75 & 96,41 \\
$3: 00$ & 96,57 & 95,91 & 97,51 & 96,30 & 97,33 & 85,51 & 98,50 & 90,50 & 96,25 & 95,24 \\
$6: 00$ & 96,60 & 78,30 & 98,01 & 85,83 & 96,56 & 79,99 & 97,96 & 76,70 & 96,50 & 78,17 \\
$9: 00$ & 96,78 & 60,64 & 97,33 & 60,64 & 96,45 & 61,22 & 97,35 & 62,80 & 96,57 & 66,30 \\
$12: 00$ & 96,11 & 45,60 & 95,42 & 39,20 & 96,38 & 41,37 & 97,48 & 40,30 & 96,48 & 52,70 \\
$24: 00$ & 95,90 & 11,24 & 95,42 & 10,74 & 95,80 & 13,50 & 96,32 & 15,60 & 95,70 & 12,80 \\
$27: 00$ & 95,89 & 7,80 & 95,31 & 5,74 & 95,82 & 4,87 & 96,38 & 6,54 & 95,81 & 6,47 \\
$30: 00$ & 95,60 & 1,06 & 95,26 & 2,05 & 95,13 & 1,08 & 96,25 & 2,47 & 95,62 & 3,35 \\
\hline
\end{tabular}

${ }^{(a)}$ Controle

${ }^{(b)}$ Cultura mista com a bactéria inativada por esterilização 
Resultados dos plaqueamentos nos ensaios com cultura mista inativada por esterilização (UFC/mL)

\begin{tabular}{ccccccc}
\hline Tempo (h) & Amostra & 1 & 2 & 3 & 4 & 5 \\
\hline $0: 00$ & Bactéria $^{(a)}$ & 0 & 0 & 0 & 0 & 0 \\
& Controle $^{(b)}$ & $7,60 \times 10^{7}$ & $1,15 \times 10^{8}$ & $4,73 \times 10^{7}$ & $7,22 \times 10^{7}$ & $6,45 \times 10^{7}$ \\
$30: 00$ & Lev+ Cult. & $1,38 \times 10^{5}$ & $1,20 \times 10^{5}$ & $8,94 \times 10^{4}$ & $6,96 \times 10^{4}$ & $1,69 \times 10^{5}$ \\
& (Esterilizada) & & & & & \\
& Controle & $6,70 \times 10^{7}$ & $1,10 \times 10^{8}$ & $7,10 \times 10^{7}$ & $5,87 \times 10^{7}$ & $4,74 \times 10^{7}$ \\
\hline
\end{tabular}

${ }^{(\mathrm{a} \text { cb) }}$ Média de 36 repetições 
APÊNDICE 4. Resultados dos ensaios utilizando cultura mista ativa, inativada por esterilização e por agentes antibacterianos

Resultados de viabilidade celular da levedura $S$. cerevisiae $(\% \mathrm{~V})$, do tratamento controle.

\begin{tabular}{cccccc}
\hline Tempo & $\mathbf{1}$ & $\mathbf{2}$ & $\mathbf{3}$ & $\mathbf{4}$ & $\mathbf{5}$ \\
\hline $0: 00$ & 96,41 & 96,95 & 97,30 & 97,32 & 96,75 \\
$3: 00$ & 96,47 & 96,96 & 97,18 & 97,41 & 96,59 \\
$6: 00$ & 96,39 & 96,38 & 97,25 & 97,18 & 96,48 \\
$9: 00$ & 96,40 & 96,41 & 97,20 & 97,21 & 96,52 \\
$12: 00$ & 96,17 & 96,12 & 97,12 & 96,98 & 96,17 \\
$24: 00$ & 95,08 & 94,33 & 96,73 & 96,75 & 94,80 \\
\hline
\end{tabular}

Resultados de viabilidade celular da levedura S. cerevisiae $(\% \mathrm{~V})$, do tratamento cultura mista inativada por penicilina $\mathrm{V}$ potássica.

\begin{tabular}{cccccc}
\hline Tempo & $\mathbf{1}$ & $\mathbf{2}$ & $\mathbf{3}$ & $\mathbf{4}$ & $\mathbf{5}$ \\
\hline $0: 00$ & 96,17 & 96,32 & 97,30 & 97,48 & 96,37 \\
$3: 00$ & 89,07 & 84,37 & 90,12 & 88,52 & 88,84 \\
$6: 00$ & 73,17 & 78,29 & 72,97 & 80,26 & 79,40 \\
$9: 00$ & 61,30 & 59,63 & 58,40 & 61,45 & 61,33 \\
$12: 00$ & 31,70 & 38,70 & 39,75 & 41,23 & 41,25 \\
$24: 00$ & 7,41 & 5,40 & 9,44 & 8,54 & 8,44 \\
\hline
\end{tabular}


Resultados de viabilidade celular da levedura S. cerevisiae $(\% \mathrm{~V})$, do tratamento cultura mista inativada por Kamoran $\mathrm{HJ}$.

\begin{tabular}{cccccc}
\hline Tempo & $\mathbf{1}$ & $\mathbf{2}$ & $\mathbf{3}$ & $\mathbf{4}$ & $\mathbf{5}$ \\
\hline $0: 00$ & 96,37 & 97,07 & 97,41 & 97,45 & 96,25 \\
$3: 00$ & 85,08 & 85,47 & 89,28 & 83,57 & 86,13 \\
$6: 00$ & 78,41 & 75,42 & 73,16 & 73,00 & 77,44 \\
$9: 00$ & 64,70 & 53,74 & 62,40 & 55,37 & 54,19 \\
$12: 00$ & 30,00 & 36,97 & 41,90 & 39,62 & 32,44 \\
$24: 00$ & 6,47 & 6,40 & 8,70 & 8,45 & 7,27 \\
\hline
\end{tabular}

Resultados de viabilidade celular da levedura S. cerevisiae $(\% \mathrm{~V})$, do tratamento cultura mista inativada por esterilização.

\begin{tabular}{cccccc}
\hline Tempo & $\mathbf{1}$ & $\mathbf{2}$ & $\mathbf{3}$ & $\mathbf{4}$ & $\mathbf{5}$ \\
\hline $0: 00$ & 96,49 & 97,85 & 97,12 & 97,42 & 96,48 \\
$3: 00$ & 91,64 & 97,50 & 91,77 & 97,44 & 92,97 \\
$6: 00$ & 83,04 & 81,26 & 81,89 & 83,65 & 78,52 \\
$9: 00$ & 69,81 & 77,49 & 72,15 & 78,74 & 65,15 \\
$12: 00$ & 49,62 & 51,10 & 51,25 & 43,72 & 52,30 \\
$24: 00$ & 20,07 & 19,71 & 17,41 & 17,81 & 19,22 \\
\hline
\end{tabular}


Resultados de viabilidade celular da levedura S. cerevisiae $(\% \mathrm{~V})$, do tratamento cultura mista ativa.

\begin{tabular}{cccccc}
\hline Tempo & $\mathbf{1}$ & $\mathbf{2}$ & $\mathbf{3}$ & $\mathbf{4}$ & $\mathbf{5}$ \\
\hline $0: 00$ & 96,51 & 97,08 & 96,98 & 97,56 & 96,85 \\
$3: 00$ & 80,06 & 85,28 & 79,03 & 85,44 & 80,83 \\
$6: 00$ & 57,81 & 58,77 & 53,62 & 57,68 & 45,00 \\
$9: 00$ & 39,47 & 28,12 & 24,25 & 26,00 & 27,60 \\
$12: 00$ & 3,94 & 6,97 & 2,37 & 5,45 & 5,23 \\
$24: 00$ & $<1,00$ & $<1,00$ & $<1,00$ & $<1,00$ & $<1,00$ \\
\hline
\end{tabular}

Resultados de viabilidade celular da levedura S. cerevisiae $(\% \mathrm{~V})$, dos tratamentos cultura mista ativa, inativada por esterilização e antibacterianos.

\begin{tabular}{cccccc}
\hline Tempo & Controle & PV & HJ & Inativada & Ativa \\
\hline $0: 00$ & 96,95 & 96,93 & 96,91 & 97,04 & 97,00 \\
$3: 00$ & 96,92 & 88,30 & 85,91 & 94,28 & 82,13 \\
$6: 00$ & 96,74 & 76,82 & 75,49 & 81,67 & 54,58 \\
$9: 00$ & 96,75 & 60,42 & 58,08 & 71,61 & 29,09 \\
$12: 00$ & 96,51 & 38,53 & 36,19 & 49,60 & 4,85 \\
$24: 00$ & 95,54 & 7,85 & 7,46 & 18,84 & $<1,00$ \\
\hline
\end{tabular}


Contagens de colônias do tratamento controle, expressos em UFC/mL.

\begin{tabular}{cccccc}
\hline Tempo & $\mathbf{1}$ & $\mathbf{2}$ & $\mathbf{3}$ & $\mathbf{4}$ & $\mathbf{5}$ \\
\hline $0: 00$ & $2,83 \times 10^{7}$ & $5,80 \times 10^{7}$ & $5,75 \times 10^{7}$ & $6,20 \times 10^{7}$ & $5,42 \times 10^{7}$ \\
$12: 00$ & $2,56 \times 10^{7}$ & $5,74 \times 10^{7}$ & $5,90 \times 10^{7}$ & $6,24 \times 10^{7}$ & $5,47 \times 10^{7}$ \\
$24: 00$ & $2,41 \times 10^{7}$ & $5,42 \times 10^{7}$ & $5,42 \times 10^{7}$ & $6,12 \times 10^{7}$ & $5,16 \times 10^{7}$ \\
\hline
\end{tabular}

Contagens de colônias do tratamento cultura mista inativada por penicilina V potássica, expressos em UFC/mL.

\begin{tabular}{cccccc}
\hline Tempo & $\mathbf{1}$ & $\mathbf{2}$ & $\mathbf{3}$ & $\mathbf{4}$ & $\mathbf{5}$ \\
\hline $0: 00$ & $6,02 \times 10^{7}$ & $2,94 \times 10^{7}$ & $5,41 \times 10^{7}$ & $6,49 \times 10^{7}$ & $6,38 \times 10^{7}$ \\
$12: 00$ & $2,77 \times 10^{6}$ & $8,10 \times 10^{6}$ & $2,42 \times 10^{6}$ & $4,45 \times 10^{6}$ & $3,94 \times 10^{6}$ \\
$24: 00$ & $4,45 \times 10^{5}$ & $1,90 \times 10^{5}$ & $3,08 \times 10^{5}$ & $6,44 \times 10^{5}$ & $7,69 \times 10^{5}$ \\
\hline
\end{tabular}


Contagens de colônias do tratamento cultura mista inativada por Kamoran $\mathrm{HJ}$, expressos em UFC/mL.

\begin{tabular}{cccccc}
\hline Tempo & $\mathbf{1}$ & $\mathbf{2}$ & $\mathbf{3}$ & $\mathbf{4}$ & $\mathbf{5}$ \\
\hline $0: 00$ & $3,21 \times 10^{7}$ & $5,28 \times 10^{7}$ & $6,22 \times 10^{7}$ & $6,79 \times 10^{7}$ & $5,92 \times 10^{7}$ \\
$12: 00$ & $8,10 \times 10^{6}$ & $2,50 \times 10^{6}$ & $4,45 \times 10^{6}$ & $3,25 \times 10^{6}$ & $2,57 \times 10^{6}$ \\
$24: 00$ & $3,22 \times 10^{5}$ & $2,74 \times 10^{5}$ & $7,94 \times 10^{5}$ & $8,04 \times 10^{5}$ & $4,12 \times 10^{5}$ \\
\hline
\end{tabular}

Contagens de colônias do tratamento cultura mista inativada por esterilização, expressos em UFC/mL.

\begin{tabular}{cccccc}
\hline Tempo & $\mathbf{1}$ & $\mathbf{2}$ & $\mathbf{3}$ & $\mathbf{4}$ & $\mathbf{5}$ \\
\hline $0: 00$ & $3,12 \times 10^{7}$ & $6,13 \times 10^{7}$ & $5,98 \times 10^{7}$ & $6,97 \times 10^{7}$ & $5,94 \times 10^{7}$ \\
$12: 00$ & $1,12 \times 10^{7}$ & $5,78 \times 10^{7}$ & $4,69 \times 10^{6}$ & $4,12 \times 10^{6}$ & $6,49 \times 10^{6}$ \\
$24: 00$ & $7,41 \times 10^{6}$ & $2,80 \times 10^{6}$ & $2,58 \times 10^{6}$ & $2,41 \times 10^{6}$ & $4,00 \times 10^{6}$ \\
\hline
\end{tabular}


Contagens de colônias do tratamento cultura mista ativa, expressos em $\mathrm{UFC} / \mathrm{mL}$

\begin{tabular}{cccccc}
\hline Tempo & $\mathbf{1}$ & $\mathbf{2}$ & $\mathbf{3}$ & $\mathbf{4}$ & $\mathbf{5}$ \\
\hline $\mathbf{0 : 0 0}$ & $3,07 \times 10^{7}$ & $5,94 \times 10^{7}$ & $6,13 \times 10^{7}$ & $7,15 \times 10^{7}$ & $6,12 \times 10^{7}$ \\
$\mathbf{1 2 : 0 0}$ & $4,32 \times 10^{8}$ & $7,94 \times 10^{8}$ & $8,75 \times 10^{8}$ & $6,94 \times 10^{8}$ & $4,54 \times 10^{8}$ \\
$\mathbf{2 4 : 0 0}$ & $2,40 \times 10^{8}$ & $5,33 \times 10^{8}$ & $5,89 \times 10^{8}$ & $2,48 \times 10^{8}$ & $3,15 \times 10^{8}$ \\
\hline
\end{tabular}




\title{
APÊNDICE 5. Determinação do efeito do tratamento enzimático
}

\author{
sobre a capacidade floculante de $L$. fermentum
}

Resultados da viabilidade celular da levedura S. cerevisiae, após dosagem das enzimas.

\begin{tabular}{cccccc}
\hline Tratamento & $\mathbf{1}$ & $\mathbf{2}$ & $\mathbf{3}$ & $\mathbf{4}$ & $\mathbf{5}$ \\
\hline Controle & 96,85 & 96,32 & 94,62 & 94,89 & 95,62 \\
Papaína & 96,48 & 96,30 & 94,08 & 94,15 & 94,93 \\
Bromelina & 96,50 & 96,25 & 94,15 & 94,04 & 94,93 \\
Ficina & 96,72 & 96,48 & 94,08 & 94,62 & 95,54 \\
\hline
\end{tabular}

Resultados das análises em Absorbância nos tratamentos com enzimas.

\begin{tabular}{cccccc}
\hline Tratamento & $\mathbf{1}$ & $\mathbf{2}$ & $\mathbf{3}$ & $\mathbf{4}$ & $\mathbf{5}$ \\
\hline Controle & 0,2095 & 0,2040 & 0,2060 & 0,2100 & 0,2400 \\
Papaina & 0,6090 & 0,6550 & 0,6410 & 0,5200 & 0,6095 \\
Bromelina & 0,5575 & 0,6580 & 0,5800 & 0,5100 & 0,5888 \\
Ficina & 0,5495 & 0,6520 & 0,5860 & 0,5400 & 0,5548 \\
\hline
\end{tabular}


Resultados dos plaqueamentos de cultivo de L. fermentum, após dosagem das enzimas, expressos em UFC/mL.

\begin{tabular}{cccc}
\hline Amostra & $\mathbf{1}$ & $\mathbf{2}$ & $\mathbf{3}$ \\
\hline Controle & $6,83 \times 10^{8}$ & $3,17 \times 10^{8}$ & $2,37 \times 10^{8}$ \\
Papaina & $6,23 \times 10^{8}$ & $3,23 \times 10^{8}$ & $2,98 \times 10^{8}$ \\
Bromelina & $5,12 \times 10^{8}$ & $3,34 \times 10^{8}$ & $2,15 \times 10^{8}$ \\
Ficina & $5,87 \times 10^{8}$ & $2,98 \times 10^{8}$ & $2,57 \times 10^{8}$ \\
\hline
\end{tabular}

